\title{
PM speciation and sources in Mexico during the MILAGRO-2006 Campaign
}

\author{
X. Querol ${ }^{1}$, J. Pey ${ }^{1}$, M. C. Minguillón ${ }^{1}$, N. Pérez ${ }^{1}$, A. Alastuey ${ }^{1}$, M. Viana ${ }^{1}$, T. Moreno ${ }^{1}$, R. M. Bernabé ${ }^{2}$, S. Blanco ${ }^{2}$, \\ B. Cárdenas ${ }^{2}$, E. $\operatorname{Vega}^{3}$, G. Sosa ${ }^{3}$, S. Escalona ${ }^{3}$, H. Ruiz ${ }^{3}$, and B. Artíñano ${ }^{4}$ \\ ${ }^{1}$ Instituto de Ciencias de la Tierra "Jaume Almera", CSIC. C/ Lluís Solé i Sabarís s/n, 08028 Barcelona, Spain \\ ${ }^{2}$ Centro Nacional de Investigación y Capacitación Ambiental, CENICA. Periférico 5000, Col. Insurgentes Cuicuilco, C.P. \\ 04530, Delegación Coyoacán, Mexico D.F., Mexico \\ ${ }^{3}$ Instituto Mexicano del Petróleo, Eje Central Lázaro Cárdenas 152, Col. San Bartolo Atepehuacan. Delegación Gustavo A. \\ Madero. 07730, Mexico, D.F, Mexico \\ ${ }^{4}$ CIEMAT, Avda. Complutense 22, 28040 Madrid, Spain
}

Received: 5 July 2007 - Published in Atmos. Chem. Phys. Discuss.: 23 July 2007

Revised: 25 September 2007 - Accepted: 5 December 2007 - Published: 14 January 2008

\begin{abstract}
Levels of $\mathrm{PM}_{10}, \mathrm{PM}_{2.5}$ and $\mathrm{PM}_{1}$ and chemical speciation of $\mathrm{PM}_{10}$ and $\mathrm{PM}_{2.5}$ were measured during the MILAGRO campaign (1st to 31st March 2006, but extended in some cases until 6th April) at four urban, one suburban, two rural background and two rural sites, with different degree of industrial influence, in the Mexico City Metropolitan Area (MCMA) and adjacent regions. $\mathrm{PM}_{10}$ and $\mathrm{PM}_{2.5}$ daily levels varied between $50-56 \mu \mathrm{g} / \mathrm{m}^{3}$ and $24-46 \mu \mathrm{g} / \mathrm{m}^{3}$ at the urban sites, $22-35 \mu \mathrm{g} / \mathrm{m}^{3}$ and $13-25 \mu \mathrm{g} / \mathrm{m}^{3}$ at the rural sites, and $75 \mu \mathrm{g} / \mathrm{m}^{3}$ and $31 \mu \mathrm{g} / \mathrm{m}^{3}$ at the industrial hotspot, lower than those recorded at some Asian mega-cities and similar to those recorded at other Latin American cities. At the urban sites, hourly $\mathrm{PM}_{2.5}$ and $\mathrm{PM}_{1}$ concentrations showed a marked impact of road traffic emissions (at rush hours), with levels of coarse PM remaining elevated during daytime. At the suburban and rural sites different PM daily patterns were registered according to the influence of the pollution plume from MCMA, and also of local soil resuspension.

The speciation studies showed that mineral matter accounted for $25-27 \%$ of bulk $\mathrm{PM}_{10}$ at the urban sites and a higher proportion (up to $43 \%$ ) at the suburban and rural sites. This pattern is repeated in $\mathrm{PM}_{2.5}$, with $15 \%$ at urban and $28 \%$ at suburban and rural sites. Carbonaceous compounds accounted for a significant proportion at the urban and industrial sites (32-46\% in $\mathrm{PM}_{10}$, and 51-55\% in $\mathrm{PM}_{2.5}$ ), markedly reduced at the suburban and rural sites (16-23\% in $\mathrm{PM}_{10}$, and $30 \%$ in $\mathrm{PM}_{2.5}$ ). The secondary inorganic aerosols accounted for $10-20 \%$ of bulk $\mathrm{PM}_{10}$ at urban, suburban, rural and industrial sites, with a higher proportion (40\%) at the industrial background site. A relatively high proportion of nitrate in rural sites was present in the coarse fraction.
\end{abstract}

Correspondence to: Xavier Querol

(xavier.querol@ija.csic.es)
Typically anthropogenic elements (As, $\mathrm{Cr}, \mathrm{Zn}, \mathrm{Cu}, \mathrm{Pb}, \mathrm{Sn}$, $\mathrm{Sb}, \mathrm{Ba}$, among others) showed considerably high levels at the urban sites; however levels of particulate $\mathrm{Hg}$ and crustal trace elements $(\mathrm{Rb}, \mathrm{Ti}, \mathrm{La}, \mathrm{Sc}, \mathrm{Ga})$ were generally higher at the suburban site.

Principal component analysis identified three major common factors: crustal, regional background and road traffic. Moreover, some specific factors were obtained for each site.

\section{Introduction}

During the last few decades a large number of epidemiological studies have shown a link between pollution by airborne particulate matter (PM) and respiratory and cardiovascular disease (Dockery et al., 1993; Künzli et al., 2000; WHO, 2003). Because a lower threshold under which no health effects are observed cannot be determined (WHO, 2003 and 2005), toxicological studies are currently aiming to identify which particle characteristics are responsible for which adverse health effects (e.g., particle number, size, surface, chemical composition). Anthropogenically emitted PM is generally considered to pose the largest threat to human health given its small grain-size, although the effects of naturally emitted PM (wind-blown dust, sea salt) cannot be discarded (CAFE, 2004).

PM air pollution in urban agglomerations comes mostly from anthropogenic sources (i.e. traffic, industrial processes, energy production, domestic and residential emissions, construction), but there is also a minor contribution from natural sources (e.g. bioaerosols, soil dust, marine aerosol, volcanic eruptions). Once emitted into the atmosphere, this complex mixture of pollutants may be transformed as a function of the

Published by Copernicus Publications on behalf of the European Geosciences Union. 


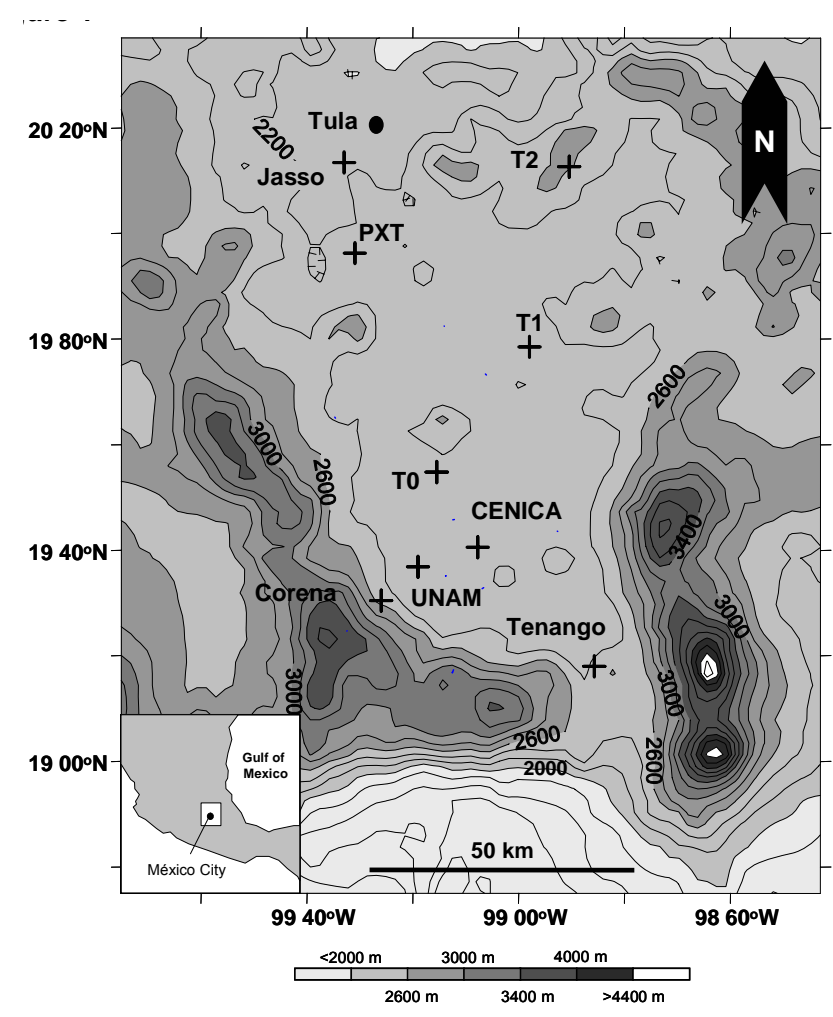

Fig. 1. Location of the PM monitoring sites in and around Mexico City and the Tula petrochemical estate.

ambient conditions and the interaction among different PM components, as well as gaseous pollutants. The PM system is especially complex in mega-cities due to:

- Large emission volumes of PM components and gaseous precursors.

- High variability of sources.

- Widespread distribution of emission sources.

- Possible long-range transport of the polluted air masses.

The WHO/UNEP report on air quality in 1992 focused on 20 mega-cities of the world, which were defined as urban agglomerations with populations of 10 million or more by the year 2000 (WHO/UNEP, 1992). The list of mega-cities included not only Tokyo, Mexico City, Cairo, Bangkok or Beijing, but also Los Angeles, New York and London. Monitoring air quality in large urban agglomerations is a pressing need in order to ensure the health and well being of urban residents, but it is also essential if we intend to prevent air pollution-related problems from occurring in emerging mega-cities which may influence both air quality and climate change on the regional, continental and global scales (Molina et al., 2007). Preventing pollution problems before they occur is usually the most cost-effective method for dealing with air pollution.

In order to better understand the evolution of trace gases and particulates originating from anthropogenic emissions in Mexico City and their impact on regional air quality and climate, a field campaign called the Megacities Initiative: Local And Global Research Observations (MILAGRO, http: //www.eol.ucar.edu/projects/milagro/) collected a wide range of meteorological, chemical, gaseous and particulate measurements during March 2006. The design of this campaign was partly based on the results obtained during the MCMA2003 Campaign (Salcedo et al., 2006; Volkamer et al., 2006; Molina et al., 2007; Zhang et al., 2007), during which exploratory field measurements of ambient aerosols were carried out in Mexico City. This campaign helped in defining physical and chemical properties of the aerosols, as well as the dominant meteorological scenarios in this mega-city, on which the current MILAGRO campaign were based. During the MILAGRO campaign measurements were obtained over a wide range of spatial scales from local, regional, and large-scale field experiments to describe the evolution of the Mexico City pollutant plume from its source and up to several hundred kilometers downwind.

The present study deals with the measurements of ambient levels of TSP, $\mathrm{PM}_{10}, \mathrm{PM}_{2.5}$ and $\mathrm{PM}_{1}$, and the speciation and source apportionment of TSP, $\mathrm{PM}_{10}$ and $\mathrm{PM}_{2.5}$ in the Mexico City Metropolitan Area (MCMA), by means of an intensive sampling campaign (1st March to 6th April 2006) of measurement, sampling and analysis of PM integrated into the 2006 MILAGRO campaign. The main goal of the present study is to interpret the variability of PM levels and composition (including trace metals) in Mexico City, as well as to identify the major emission sources (of PM and trace metals) in the area.

Other studies on PM characterization (some of them with speciation and source identification) done in Mexico city are those published by Miranda et al. (1996 and 2005) and Aldape et al. (2005), Johnson et al. (2006), Salcedo et al. (2006), Stone et al. (2007), Molina et al. (2007), Moffett et al. (2007), Yokelson et al. (2007). Furthermore, Mugica et al. (2002) reported on levels of trace elements in PM; and Vega et al. (2001) on the chemical characterization of re-suspension source emission profiles.

\section{Methodology}

\subsection{Measurements and sampling}

Measurement and sampling of PM were carried out at the following monitoring stations (Table 1 and Fig. 1):

T0.

This monitoring station is located to the northwestern part of the basin of Mexico City. It is an urban background site influenced by road traffic fresh emissions $(300 \mathrm{~m}$ from four major roads surrounding it), domestic and residential emissions, but also potentially influenced by local industrial emissions and from the Tula industrial area (around $60 \mathrm{~km}$ to the northnorthwest, in the Hidalgo State). This station was equipped 
Table 1. Location of the monitoring stations.

\begin{tabular}{lllll}
\hline Site & Coordinates & & Type of site \\
\hline UNAM & $19^{\circ} 19^{\prime} 31^{\prime \prime} \mathrm{N}$ & $99^{\circ} 10^{\prime} 51^{\prime \prime} \mathrm{W}$ & $2220 \mathrm{~m}$ a.s.l. & urban background \\
CENICA & $19^{\circ} 21^{\prime} 32^{\prime \prime} \mathrm{N}$ & $99^{\circ} 04^{\prime} 25^{\prime \prime} \mathrm{W}$ & $2232 \mathrm{~m}$ a.s.l. & urban background \\
T0 & $19^{\circ} 29^{\prime} 22^{\prime \prime} \mathrm{N}$ & $99^{\circ} 08^{\prime} 22^{\prime \prime} \mathrm{W}$ & $2243 \mathrm{~m}$ a.s.l. & urban background \\
$\mathrm{T} 1$ & $19^{\circ} 42^{\prime} 14^{\prime \prime} \mathrm{N}$ & $98^{\circ} 57^{\prime} 45^{\prime \prime} \mathrm{W}$ & $2270 \mathrm{~m}$ a.s.l. & suburban \\
T2 & $20^{\circ} 01^{\prime} 14^{\prime \prime} \mathrm{N}$ & $98^{\circ} 54^{\prime} 09^{\prime \prime} \mathrm{W}$ & $2542 \mathrm{~m}$ a.s.l. & rural background \\
Tenango & $19^{\circ} 09^{\prime} 18^{\prime \prime} \mathrm{N}$ & $98^{\circ} 51^{\prime} 50^{\prime \prime} \mathrm{W}$ & $2377 \mathrm{~m}$ a.s.l. & rural background \\
Corena & $19^{\circ} 15^{\prime} 52^{\prime \prime} \mathrm{N}$ & $99^{\circ} 18^{\prime} 07^{\prime \prime} \mathrm{W}$ & $2300 \mathrm{~m}$ a.s.l. & urban background \\
Jasso & $20^{\circ} 01^{\prime} 02^{\prime \prime} \mathrm{N}$ & $99^{\circ} 18^{\prime} 55^{\prime \prime} \mathrm{W}$ & $2125 \mathrm{~m}$ a.s.l. & rural-industrial hotspot \\
PXT & $19^{\circ} 51^{\prime} 44^{\prime \prime} \mathrm{N}$ & $99^{\circ} 17^{\prime} 43^{\prime \prime} \mathrm{W}$ & $2329 \mathrm{~m}$ a.s.l. & rural close to industry \\
\hline
\end{tabular}

with high volume samplers fitted with cut off inlets for $\mathrm{PM}_{10}$ (Wedding, $\left.68 \mathrm{~m}^{3} / \mathrm{h}\right)$ and $\mathrm{PM}_{2.5}\left(\mathrm{MCV}, 30 \mathrm{~m}^{3} / \mathrm{h}\right)$ from $1 \mathrm{st}$ March to 4th April 2006 ( $\mathrm{n}=35,12 \mathrm{~h}$ integrated samples), and 6th to 29th March 2006 ( $\mathrm{n}=24,12 \mathrm{~h}$ integrated samples), respectively. This monitoring site was also equipped with a laser spectrometer (GRIMM 1107, US1) for real time measurement of hourly levels of $\mathrm{PM}_{10}, \mathrm{PM}_{2.5}$ and $\mathrm{PM}_{1}$, from 19th to 30th March 2006.

\section{CENICA.}

This is an urban background station, with similar characteristics to T0, but located in the southeastern side of the city of Mexico. This station was equipped with a high volume sampler fitted with a cut off inlet for $\mathrm{PM}_{10}$ (Wedding, $68 \mathrm{~m}^{3} / \mathrm{h}$ ) from 1st March to 6th April 2006 ( $\mathrm{n}=38,12$ and 24h integrated samples). This monitoring site was also equipped with a laser spectrometer (GRIMM 1108) for real time measurement of hourly levels of TSP, $\mathrm{PM}_{10}, \mathrm{PM}_{2.5}$ and $\mathrm{PM}_{1}$, from 8th to 29th March 2006.

\section{UNAM.}

This is an urban background station, influenced by road traffic and residential emissions, with similar characteristics to T0 and CENICA, but located on the southern side of the city of Mexico. This station was equipped with a high volume sampler and a cut off inlet for $\mathrm{PM}_{10}$ (Wedding, $68 \mathrm{~m}^{3} / \mathrm{h}$ ) from 1st to 15 th March 2006 ( $\mathrm{n}=7$, only $24 \mathrm{~h}$ samples).

Jasso (Subestacion) and PXT.

These two rural background sites were located in the vicinity of a heavy industrialized area, the Tula-Vito-Apasco industrial corridor, $60 \mathrm{~km}$ north-northwest from the Mexico City downtown. Jasso and PXT were $6 \mathrm{~km}$ southwest and $25 \mathrm{~km}$ south from a large refinery and a power plant (Tula estate), respectively. At the two sites $\mathrm{PM}_{10}$ and $\mathrm{PM}_{2.5}$ samples were collected by using portable low volume samplers (MiniVol) operating at a flow rate of $0.3 \mathrm{~m}^{3} / \mathrm{h}$ and previously calibrated under standard conditions. Samples were collected from
00:00 to 24:00 h each day from 24th of March to 20th April 2006 , with a total number of samples of $\mathrm{n}=55$ for $\mathrm{PM}_{10}$, and $\mathrm{n}=55$ for $\mathrm{PM}_{2.5}$. Additionally, medium volume sequential filter samplers (SFS) operated at a flow rate of $6.8 \mathrm{~m}^{3} / \mathrm{h}$ and equipped with $\mathrm{PM}_{2.5}$ inlets were used to collect 12-hour samples from 7th to 20th April $2006(\mathrm{n}=56)$.

T1.

This is a suburban background site located around $50 \mathrm{~km}$ to the north of Mexico City, in an area isolated from major urban agglomerations but close to small populated agglomerations, and around $500 \mathrm{~m}$ from the closest road. The station was equipped with three high volume samplers (Wedding, $68 \mathrm{~m}^{3} / \mathrm{h}$ ) with TSP, $\mathrm{PM}_{10}$ and $\mathrm{PM}_{2.5}$ cutoff inlets from 1st to 29th March 2006 ( $\mathrm{n}=25,24$ and 23, $12 \mathrm{~h}$ integrated samples, respectively).

$\mathrm{T} 2$.

This is a rural background site located around $90 \mathrm{~km}$ to the north of the city of Mexico, in the surroundings of a farm isolated from major urban agglomerations, and around $2 \mathrm{~km}$ from the closest road. The monitoring site was equipped with a Wedding high volume $\left(68 \mathrm{~m}^{3} / \mathrm{h}\right)$ sampler with a $\mathrm{PM}_{10}$ cut off inlet from 9th to 17th March $2006(\mathrm{n}=8)$.

\section{CORENA and TENANGO.}

At these urban background and rural background sites, respectively, two laser spectrometers (GRIMM 1107) for real time measurements of hourly levels of $\mathrm{PM}_{10}, \mathrm{PM}_{2.5}$ and $\mathrm{PM}_{1}$ were installed from 1st to 4th April 2006 at CORENA and 28th March to 7th April 2006 at TENANGO.

The main objective of the measurements performed at the urban background sites was the characterization and source apportionment of urban aerosols in MCMA. Elucidation of the origin of particulate mercury in $\mathrm{PM}_{10}$ was of particular interest here. In contrast, the main objective of data collection at the rural background site was to investigate the 


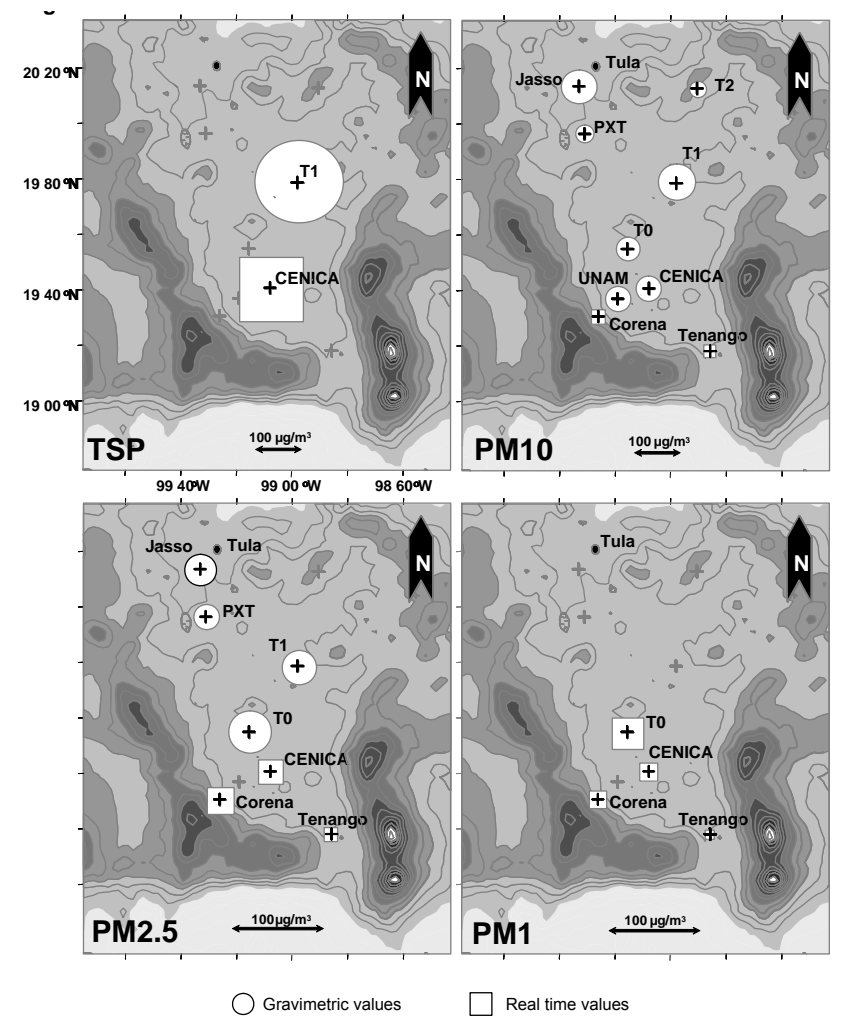

Fig. 2. Graphical view of the $\mathrm{PM}\left(\mathrm{TSP}, \mathrm{PM}_{10}, \mathrm{PM}_{2.5}\right.$ and $\left.\mathrm{PM}_{1}\right)$ concentrations shown in Table 2 superimposed onto Fig. 1 (location map) to allow easier comparison. Real time values (squares) are only used when gravimetric values (circles) were not available.

influence of the emissions from MCMA on the composition of the atmospheric aerosols in the surrounding rural sites.

Samples from T0, T1, T2, UNAM and CENICA obtained with the high volume samplers were collected at all sites on quartz micro-fiber filters (Pallflex for the Wedding instruments and Schleicher \& Schuell for the MCV instruments), conditioned for subsequent analysis. High volume samplers were operated one out of every two days along the field campaign. Two $12 \mathrm{~h}$ samples were collected every sampling day (from $08: 00 \mathrm{~h}$ to $20: 00 \mathrm{~h}$ and $20: 00 \mathrm{~h}$ to $08: 00 \mathrm{~h}$ local time), with the exception of UNAM and T2 (24h samples). Samples from Jasso and PXT sites were collected on $47 \mathrm{~mm}$ Teflon-membrane $(2 \mu \mathrm{m}$ pore size, Gelman Scientific, Ann Arbor, MI, USA) and quartz-fiber (Pallflex Products Corp., Putnam, CT, USA) filters. Teflon filters were used for mass analyses, trace element analyses and light transmission, whereas quartz filters were used for ion, elemental and organic carbon analyses. Although two different types of quartz filters were used, their quality was checked by each of the research groups in their respective laboratory.

Real time measurements of PM were obtained with two models of laser spectrometers, GRIMM 1107 and 1108. These instruments perform particulate size measurements by

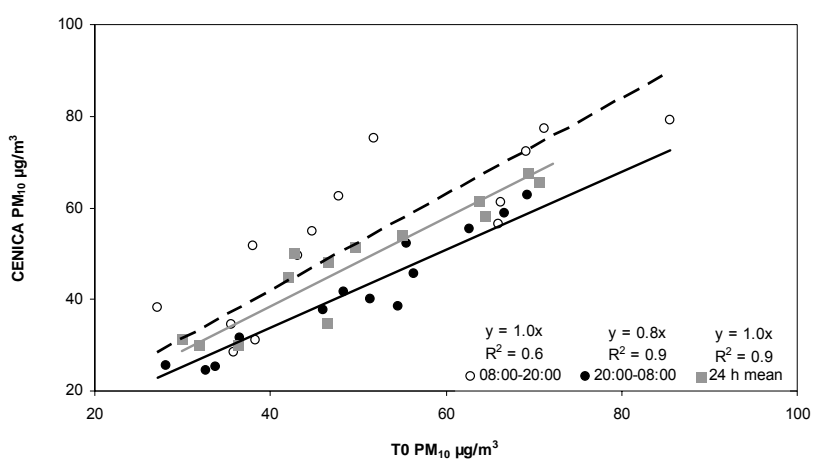

Fig. 3. Comparison of 12 and $24 \mathrm{~h} \mathrm{PM}_{10}$ levels simultaneously measured at T0 and CENICA (two urban background sites), Mexico City, during the MILAGRO campaign.

90-degree laser light scattering. Sampling air (1.2 1/min) passes through a flat laser beam produced by an ultra low maintenance laser diode. A 15-channel $(0.3-25 \mu \mathrm{m})$ pulse height analyzer for size classification detects the scattering signals. These counts from each precisely sized pulse channel are converted to mass using a density equation included in the instrument software. In addition, real time measurements obtained by the optical counter were corrected with the regression equations (in all cases $\mathrm{R}^{2}>0.8$ ) obtained between the comparison of gravimetric PM levels (aerodynamic diameter) determined by the standard high volume gravimetric method, and real time (optical counts) measurements, independently for $\mathrm{PM}_{10}$ and $\mathrm{PM}_{2.5}$ fractions. $\mathrm{PM}_{1}$ data was corrected according to the $\mathrm{PM}_{2.5}$. We have checked at laboratory that in some cases this may result in a slight overestimation of levels of $\mathrm{PM}_{1}$.

\subsection{Chemical and microscopy analysis}

Samples were conditioned after sampling $(50 \pm 4 \%$ humidity and $22 \pm 3^{\circ} \mathrm{C}$ during $48 \mathrm{~h}$ ) prior to gravimetric determination of the PM mass were stabilized (carried out in the same controlled chamber as filters). Levels of major and trace elements were determined in bulk sample acidic digestions ( $\left.\mathrm{HF}: \mathrm{HClO}_{4}: \mathrm{HNO}_{3}\right)$ by means of Inductively Coupled Atomic Emission Spectroscopy, ICP-AES (IRIS Advantage TJA Solutions, THERMO), and Inductively Coupled Plasma Mass Spectroscopy, ICP-MS (X Series II, THERMO), respectively. Levels of particulate mercury were determined by means of a Hg Gold Amalgam Atomic Absorption analyzer (AMA-254, LECO instruments). The content of $\mathrm{Cl}^{-}$, $\mathrm{SO}_{4}^{2-}$ and $\mathrm{NO}_{3}^{-}$was determined by means of Ion Chromatography HPLC (High Pressure Liquid Chromatography) using a WATERS IC-pak ${ }^{T M}$ anion column and WATERS 432 conductivity detector, and $\mathrm{NH}_{4}^{+}$was determined by means of a Selective Electrode (MODEL 710 A+, THERMO Orion). Total Carbon was determined by means of a LECO elemental analyzer. OC and EC levels were determined on a selected number of samples to determine the ratios OC/EC 

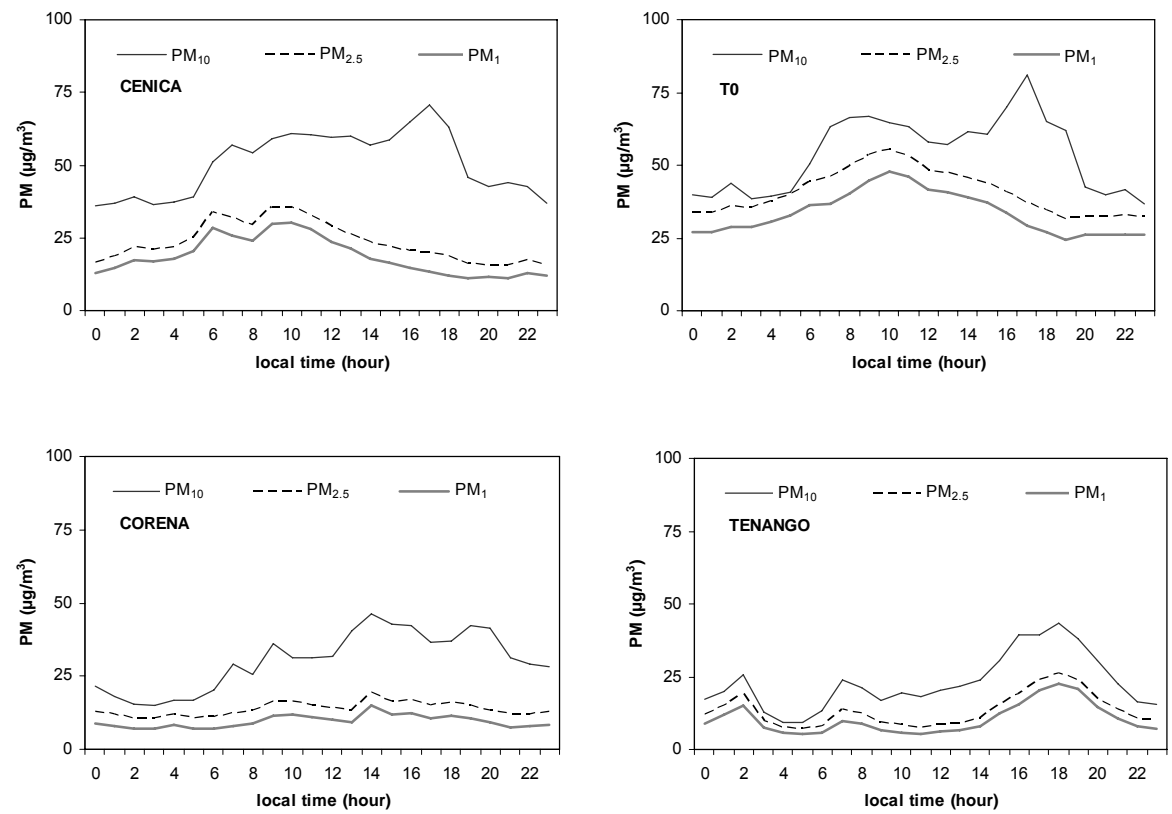

Fig. 4. Mean hourly PM levels measured during the MILAGRO campaign at 2 urban background sites of Mexico City, CENICA and T0, and at two southern sites, Tenango and Corena.

by Thermo-Optical Reflectance (TOR) according to the method described by Fung et al. (2002). Sample treatment and analytical details are described in Querol et al. (2001). Indirect determinations from analytical data were obtained for: a) $\mathrm{CO}_{3}^{2-}$, determined from $\mathrm{Ca}$ content, assuming that this element is mainly present as calcite $\left(\mathrm{CaCO}_{3} ; \mathrm{CO}_{3}^{2-}=\right.$ $\left.1.5^{*} \mathrm{Ca}\right)$; b) $\mathrm{SiO}_{2}$, determined from the $\mathrm{Al}$ content on the basis of prior studies in Mexico city $\left(\mathrm{SiO}_{2}=2 * \mathrm{Al}_{2} \mathrm{O}_{3}\right.$; Johnson et al., 2006); c) organic matter, determined as $1.6^{*} \mathrm{OC}$, based on Turpin and Lim, 2001). Selected samples were also studied under an environmental Scanning Electron Microscope (SEM, FEI QUANTA 200), with chemical analyses of individual particles being performed manually on uncoated samples using an energy dispersive X-ray microanalysis system (EDX). Microscope conditions were working distance of $10 \mathrm{~mm}$, accelerating voltage of $20 \mathrm{kV}$, a beam spot size number 2 with a beam current of approximately $1.00 \mu \mathrm{A}$, and a spectrum acquisition time of $30 \mathrm{~s}$ live time, with particles being analyzed in its centre. The time under vacuum $(130 \mathrm{~Pa})$ before the analysis is about 2-3 min.

\subsection{Meteorological data}

At T0 site, a 3-D sonic anemometer (Campbell Scientific, model CSAT3) was used to measure horizontal and vertical wind components at $1 \mathrm{~Hz}$. Temperature, relative humidity and atmospheric pressure were registered using Vaisala HMP-series sensors. All equipments were deployed at $12 \mathrm{~m}$ above the ground level. Data was kindly made available for MILAGRO participants by W. Eichinger from the University of Iowa.

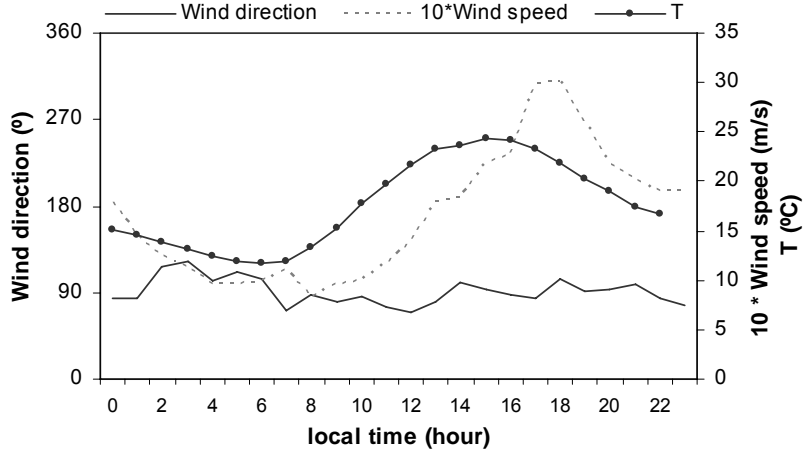

Fig. 5. Mean hourly temperature, wind direction (vectorial mean) and wind speed recorded at T0 from 1st to 26th March 2006.

\section{Atmospheric dynamics}

Mexico City is located in an elevated basin, $2240 \mathrm{~m}$ above mean sea level (m a.s.l.). Surrounding mountains on the west, south and east reach $1000 \mathrm{~m}$ above the basin, and two volcanoes at the southeast reach over $5000 \mathrm{~m}$ a.s.l. The basin is opened to the north and southeast, where a small gap between mountains allows entering of cold and fresh air during evenings, cleaning up the basin most of the time. Fast and Zhong (1998) emphasize the importance of vertical mixing and mountain winds in the transport of the Mexico City urban plume first towards the south during the day and then back over the city to the north during nightime. Clear skies, low humidity, and weak winds aloft associated with highpressure systems are usually observed over Mexico during March (Fast et al., 2007). 
Table 2. Mean TSP, $\mathrm{PM}_{10}, \mathrm{PM}_{2.5}$ and $\mathrm{PM}_{1}\left(\mu \mathrm{g} / \mathrm{m}^{3}\right)$ levels obtained at the different monitoring stations, for the periods indicated.

\begin{tabular}{|c|c|c|c|c|c|c|}
\hline Location & Rea & \multicolumn{2}{|c|}{ Real time measurements } & $\mathrm{PM}_{10}$ & $\mathrm{PM}_{2.5}$ & $\mathrm{PM}_{1}$ \\
\hline CENICA & 08-29 March 2006 & & 144 & 50 & 24 & 19 \\
\hline T0 & 19-30 March 2006 & & & 56 & 40 & 33 \\
\hline Tenango & 28 March 2006-06 April 2006 & & & 22 & 13 & 10 \\
\hline Corena & 01-04 April 2006 & & & 30 & 25 & 17 \\
\hline \multicolumn{7}{|c|}{ PM samplers (gravimetry) } \\
\hline CENICA & 01 March 2006 to 06 April 2006 & 38 & & 53 & & \\
\hline T0 & 01 March 2006 to 06 April 2006 & 37,27 & & 50 & 40 & \\
\hline $\mathrm{T} 1$ & 01-29 March 2006 & $23,24,25$ & 193 & 80 & 33 & \\
\hline UNAM & 01-15 March 2006 & 7 & & 54 & & \\
\hline $\mathrm{T} 2$ & 09-17 March 2006 & 8 & & 34 & & \\
\hline Tula- PXT & 24 March 2006-20 April 2006 & 28,42 & & 37 & 26 & \\
\hline Tula- Jasso & 24 March 2006-20 April 2006 & 28,42 & & 75 & 31 & \\
\hline
\end{tabular}

Based on MILAGRO field measurements and large-scale analyses Fast et al. (2007) defined three regimes that characterized the overall meteorological conditions: before 14th March (mostly sunny and dry conditions), between 14th and 23rd March (increase in humidity and development of late afternoon convection), and after 23rd March (higher humidity, afternoon convection, and precipitation). The synoptic conditions during March for Mexico City are described in detail by Fast et al. (2007), with winds from the north and east during the first week, west then southwest from 9-12th, variable from 13-18th, southwest between 19-20th, and finally westerly winds for the rest of the month. Wind speeds at $500 \mathrm{hPa}$ exceeded $15 \mathrm{~m} / \mathrm{s}$ during 9 th-11th March and 19th20th March, whereas at $700 \mathrm{hPa}$ they were usually less than $5 \mathrm{~m} / \mathrm{s}$.

According to Doran et al. (2007), on 10th, 18th, 19th, 20th, 22nd, and 24th March T1 and T2 were influenced by the Mexico's emission plume. This type of air mass circulation coincides with that reported by Molina et al. (2007) during episodes of ozone transport towards the northeast from MCMA.

\section{Results}

\subsection{PM levels}

Table 2 summarizes the mean TSP, $\mathrm{PM}_{10}, \mathrm{PM}_{2.5}$ and $\mathrm{PM}_{1}$ levels measured at the different monitoring stations (also see Fig. 2). Although the measuring periods were not simultaneous at all the monitoring sites, it is evident that the mean $\mathrm{PM}_{10}$ levels measured at the urban background sites of Mexico City for the study period fall in a narrow range, from 50 to $56 \mu \mathrm{g} / \mathrm{m}^{3}$, the values from real time and gravimetry being very similar. For $\mathrm{PM}_{2.5}$ and $\mathrm{PM}_{1}$ a wider range of levels was measured, with 24 to 40 and 19 to $33 \mu \mathrm{g} / \mathrm{m}^{3}$, respectively. At the Jasso rural-industrial site $\mathrm{PM}_{10}$ levels measured increased up to $75 \mu \mathrm{g} / \mathrm{m}^{3}$, although $\mathrm{PM}_{2.5}$ levels $\left(31 \mu \mathrm{g} / \mathrm{m}^{3}\right)$ were in the range defined for Mexico City $\left(35 \mu \mathrm{g} / \mathrm{m}^{3}\right)$ (Vega et al., 2004). At the rural sites PXT and T2 PM levels fall within the range 34 to $37 \mu \mathrm{g} \mathrm{PM} 10 / \mathrm{m}^{3}$ and $26 \mu \mathrm{g} \mathrm{PM} \mathrm{P}_{2.5} / \mathrm{m}^{3}$. Levels at the suburban site T1 $\left(193,80\right.$ and $33 \mu \mathrm{g} / \mathrm{m}^{3}$ for TSP, $\mathrm{PM}_{10}$ and $\mathrm{PM}_{2.5}$ ) and the Jasso rural-industrial site were markedly higher probably due to intensive local soil dust resuspension and to the influence of a cement plant and limestone quarry at Jasso. It should be noted that at the urban sites, the instrumentation was located on the terrace of buildings and that coarse PM concentrations (e.g. TSP) at ground level would probably be much higher.

Although the above PM levels may be considered as relatively high when compared with the US or European air quality standards, they are markedly lower than PM levels measured at Asian mega-cities (or large cities). Thus, as shown in Table 3, most large cities in China and India record annual mean levels of $80-150 \mu \mathrm{g} \mathrm{PM}_{10} / \mathrm{m}^{3}$ and 60 $125 \mu \mathrm{g} \mathrm{PM}_{2.5} / \mathrm{m}^{3}$. Moreover, data reported by Clean Air Initiatives for Asian cities (2006) show that, with the exception of Tokyo, most Asian mega-cities ( $>10$ million population) and large cities exceed $80 \mu \mathrm{g} \mathrm{PM}_{10} / \mathrm{m}^{3}$ as a mean annual average (mean 2005 annual levels in $\mu \mathrm{g} \mathrm{PM}_{10} / \mathrm{m}^{3}: 51$ Bangkok; 155 Beijing; 115 Hanoi, 80 Jakarta; 110 Calcutta; 80 Mumbai; 160 New Delhi; 70 Seoul; 100 Shanghai; 35 Tokyo). These levels are up to 3 times higher than those recorded in Mexico City during the MILAGRO campaign, although it must be taken into account that the PM concentrations presented in this study are not annual means, as it is the case for the Asian cities described above.

Similar levels of $\mathrm{PM}_{10}$ were measured at the two urban background sites with the largest data coverage (CENICA and T0), with a simultaneous variation in the levels of PM measured at both sites $\left(\alpha=1.0, \mathrm{R}^{2}=0.9\right.$ : see Fig. 3). Daylight $12 \mathrm{~h} \mathrm{PM}_{10}$ levels were similar $\left(\alpha=1.0, \mathrm{R}^{2}=0.6\right)$. The variation of $\mathrm{PM}_{10}$ levels was even better correlated at the two sites during the night $\left(\mathrm{R}^{2}=0.9\right)$, although $20 \%$ higher values $(\alpha=0.8)$ were recorded at T0. The higher night-time values 
at $\mathrm{T} 0$ could be related to aged pollutant transport towards the north, as described by Fast and Zhong (1998). These results indicate that both stations are indeed representative of urban background $\mathrm{PM}_{10}$ climate in Mexico City and that, in agreement with results from Molina et al. (2007) for MCMA-2003 campaign, $\mathrm{PM}_{10}$ levels varied on a relatively large scale during the MILAGRO campaign. The lower diurnal correlation of the $\mathrm{PM}_{10}$ levels is probably attributable to the influence of soil resuspension at CENICA. In this context, an important difference between the relative contributions of coarse and fine PM was detected. $\mathrm{PM}_{10}$ at CENICA had a larger proportion of coarse $\mathrm{PM}\left(50 \% \mathrm{PM}_{2.5-10}\right)$ whereas at $\mathrm{T} 0$ the finer fraction was dominant (only $30 \% \mathrm{PM}_{2.5-10}$ ), probably due to higher traffic exhaust emissions in the vicinity of T0.

At the suburban and rural sites the coarse fraction accounted from 30 to $60 \%$ of the $\mathrm{PM}_{10}$ mass. This large variation in the relative proportion of fine and coarse fraction is due to a high impact of local soil resuspension at T1 and to resuspension of dust from a nearby cement plant and limestone quarry at Jasso. At T1 and Jasso sites, these large resuspended dust contributions accounted for high levels of $\mathrm{PM}_{10}$ and $\mathrm{PM}_{2.5}$, when compared with the other rural sites (by a factor of 2 to 4 ). The fraction $\mathrm{PM}_{1-2.5}$ was about $20 \%$ of total $\mathrm{PM}_{2.5}$ in the urban sites, which is similar to the findings reported by Salcedo et al. (2006).

The hourly evolution of PM levels measured during the entire MILAGRO campaign at the urban background sites of Mexico City, CENICA and T0 (Fig. 4), was most strongly influenced by the peak fine PM concentrations recorded during the morning traffic rush hours. This pattern coincides with data from Chow et al. (2002) as well as the report of the monitoring network in Mexico City (RAMA) during April 2004 at the Metropolitan University as reported by Salcedo et al. (2006). The coarse fraction increased also at morning rush hours, remaining high and reaching the maximum at $16-18 \mathrm{~h}$, followed by a nightly decrease (less urban dust resuspension). The 2 monitoring sites followed the same mean daily pattern, with a very clear afternoon coarse PM peak, probably attributable to the higher wind speed typically recorded at Mexico City during the afternoon in this period of the year (Fig. 5).

At the two sites located to the South of Mexico City, different PM daily trends were recorded, with the maximum PM being registered in the afternoon, at 19:00 $\mathrm{h}$ at Tenango and at $14: 00 \mathrm{~h}$ at Corena. This is probably due to the transport of the urban plume from Mexico, which reaches Corena (south) at 14:00 $\mathrm{h}$ and Tenango (southeast) at 18:00-19:00 h. Both fine and coarse fractions are affected by this transport. This is supported by the measurements at the rural site Tenango plotted in Fig. 6, showing Mexico City's plume impact causing high levels of $\mathrm{PM}_{1}$ during the period 15:00-21:00 $\mathrm{h}$ and much reduced over the rest of the day.

As expected, $\mathrm{PM}_{10}$ levels were at all sites higher (by a factor around 1.3) during daylight, as a consequence of the

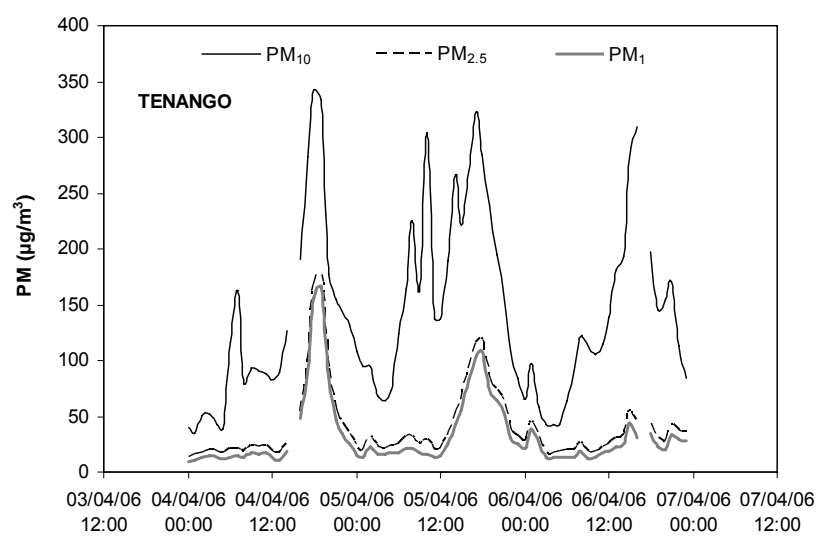

Fig. 6. Hourly PM levels measured at the rural site Tenango, showing the Mexico City's plume impact causing high levels of $\mathrm{PM}_{1}$.

higher atmospheric emissions and turbulence. This difference was much reduced in the case of $\mathrm{PM}_{2.5}$.

Concerning the daily evolution of PM levels measured at the two urban background sites, CENICA and T0 (Fig. 7), two definite periods can be clearly identified. The first one lasted from the beginning of the measurements until 23rd March, and was characterized by relatively high levels of $\mathrm{PM}_{10}$ (a mean of $57 \mu \mathrm{g} / \mathrm{m}^{3}$ ), with a dominant coarse grain size $\left(\mathrm{PM}_{2.5-10}\right.$ and $\mathrm{PM}_{1-10}$ loads were $57 \%$ and $67 \%$ of bulk $\mathrm{PM}_{10}$ ) due probably to the influence of resuspension of urban dust. The second period started on 23rd March and lasted until the end of the month, and was characterized by lower $\mathrm{PM}_{10}$ levels $\left(35 \mu \mathrm{g} / \mathrm{m}^{3}\right)$ and a finer grain size $\left(\mathrm{PM}_{2.5-10}\right.$ and $\mathrm{PM}_{1-10}$ loads were $41 \%$ and $50 \%$ of bulk $\mathrm{PM}_{10}$ ). This was coincident with the last meteorological period of the field campaign when precipitation was frequent and the resuspension of urban dust diminished. This wet period also influenced $\mathrm{PM}_{2.5}$ and $\mathrm{PM}_{1}$ levels which slightly decreased (by $18 \%$ ), but not as much as $\mathrm{PM}_{10}$ (by $40 \%$ ). In addition to the above described mean hourly patterns (defined by road traffic emissions and wind velocity/dust resuspension), two additional types of PM episodes were identified. One from 04 to $06 \mathrm{~h}$ with relatively high levels of $\mathrm{PM}_{1}$ occurring on 14th, 18th, 21st, 22nd and 25th to 27th March 2006. During most of those days, $\mathrm{PM}_{2.5}$ levels were higher during the night than during daytime. These episodes are also reflected in the mean hourly evolution obtained for the urban sites (Fig. 4), and as interpreted already by Doran et al. (2007) on the basis of real time measurements of OC and EC at T1 and T2, they may be attributed to the trapping of pollutants in the Mexico City area overnight and during the morning hours in a shallow surface layer before the rapid growth of the mixing layer commences around 07:00 h. Another single episode of coarse $\mathrm{PM}_{10}$ occurred from 10:00 to 20:00 h on 19th March 2006 at CENICA and T0, probably caused by local dust resuspension due to high wind velocity as recorded by Fast et al. (2007) during this day, compared with the rest of the campaign. 
Table 3. Mean $\mathrm{PM}_{10}$ and $\mathrm{PM}_{2.5}$ levels and $\mathrm{PM}_{10}$ speciation from large Asian cities compared with the data obtained in this study for Mexico City.* Only water soluble fraction.

\begin{tabular}{|c|c|c|c|c|c|c|c|c|c|c|c|c|c|c|c|}
\hline \multirow[b]{2}{*}{$\mu \mathrm{g} / \mathrm{m}^{3}$} & \multirow[t]{2}{*}{ Seoul $^{a}$} & \multirow[t]{2}{*}{ Tokyo $^{b}$} & \multirow[t]{2}{*}{ Taiwan $^{b}$} & \multicolumn{2}{|c|}{ China $^{(c-g)}$} & \multirow{2}{*}{$\begin{array}{l}\text { China }^{h} \\
\text { Nanjing }\end{array}$} & \multicolumn{2}{|c|}{ Calcutta $^{i}$} & \multirow[t]{2}{*}{ New Delhi ${ }^{j, k}$} & \multirow[t]{2}{*}{ Mumbai $^{l}$} & \multirow[t]{2}{*}{ S. de Chile ${ }^{m}$} & \multirow[t]{2}{*}{ Buenos Aires $^{n}$} & \multirow[t]{2}{*}{ Sao Paulo $^{m}$} & \multicolumn{2}{|c|}{ Mexico This study } \\
\hline & & & & $\min$ & $\max$ & & $\min$ & $\max$ & & & & & & CENICA & T0 \\
\hline $\mathrm{PM}_{2.5}$ & 56 & NR & NR & 50 & 127 & 222 & NR & NR & NR & NR & 68 & 35 & 35 & 24 & 46 \\
\hline $\mathrm{PM}_{10}$ & 109 & 35 & NR & 79 & 197 & 317 & 140 & 197 & 278 & NR & 115 & 50 & 77 & 52 & 52 \\
\hline $\mathrm{OC}+\mathrm{EC}$ & NR & NR & NR & 14 & 31 & $29^{*}$ & 2 & 3 & NR & NR & NR & NR & NR & 14 & 16 \\
\hline $\mathrm{Al}_{2} \mathrm{O}_{3}$ & NR & NR & NR & 5 & 11 & NR & NR & NR & NR & NR & NR & NR & NR & 3 & 2 \\
\hline $\mathrm{Ca}$ & NR & 1 & 2 & 2 & 10 & $5^{*}$ & NR & NR & NR & NR & NR & NR & NR & 1 & 2 \\
\hline $\mathrm{Fe}$ & NR & 1 & 1 & 1 & 3 & NR & 0.1 & 0.1 & NR & NR & NR & NR & NR & 1 & 1 \\
\hline K & NR & 0.4 & 1 & 2 & 4 & $3^{*}$ & NR & NR & NR & NR & NR & 1 & NR & 1 & 1 \\
\hline $\mathrm{Mg}$ & NR & 0.2 & 1 & 1 & 2 & $1^{*}$ & NR & NR & NR & NR & NR & NR & NR & 0.5 & 0.4 \\
\hline $\mathrm{Na}$ & NR & 1 & 8 & 1 & 8 & $4^{*}$ & NR & NR & NR & NR & NR & 2 & NR & 0.5 & 0.5 \\
\hline $\mathrm{SO}_{4}^{2-}$ & NR & NR & 10 & 15 & 30 & 18 & 1 & 2 & NR & NR & NR & 7 & NR & 5 & 5 \\
\hline $\mathrm{NO}_{3}^{-}$ & NR & NR & NR & 3 & 20 & 9 & 0.2 & 0.2 & NR & NR & NR & 4 & NR & 4 & 4 \\
\hline $\mathrm{Cl}^{-3}$ & NR & NR & NR & 1 & 5 & 2 & 1 & 1 & NR & NR & NR & 5 & NR & 1 & 1 \\
\hline $\begin{array}{l}\mathrm{NH}_{4}^{+} \\
\mathrm{ng} / \mathrm{m}^{3}\end{array}$ & NR & NR & NR & 4 & 13 & 11 & NR & NR & NR & NR & NR & 3 & NR & 2 & 2 \\
\hline As & NR & 2 & 50 & 6 & 66 & NR & NR & NR & NR & 6 & NR & NR & NR & 5 & 6 \\
\hline $\mathrm{Cr}$ & NR & 6 & 20 & 6 & 40 & NR & 7 & 6 & 280 & 100 & NR & NR & NR & 1 & 4 \\
\hline $\mathrm{Zn}$ & NR & 233 & 380 & 295 & 1409 & NR & 490 & 535 & 600 & NR & NR & NR & NR & 100 & 482 \\
\hline $\mathrm{Sr}$ & NR & NR & 10 & 30 & 40 & NR & NR & NR & NR & NR & NR & NR & NR & 9 & 16 \\
\hline $\mathrm{Pb}$ & NR & 64 & 90 & 82 & 409 & NR & 40 & 120 & 660 & 900 & NR & NR & NR & 32 & 111 \\
\hline $\mathrm{Ni}$ & NR & 5 & 50 & 4 & 75 & NR & 7 & 8 & 250 & 160 & NR & NR & NR & 3 & 5 \\
\hline Co & NR & 1 & - & 1 & 5 & NR & NR & NR & NR & NR & NR & NR & NR & 0.5 & 1 \\
\hline $\mathrm{Cd}$ & NR & 2 & 10 & 9 & 11 & NR & 2 & 5 & 80 & NR & NR & NR & NR & 1 & 3 \\
\hline $\mathrm{Mn}$ & NR & 30 & 70 & 23 & 186 & NR & 2 & 2 & NR & 860 & NR & NR & NR & 20 & 32 \\
\hline V & NR & 6 & 10 & 5 & 18 & NR & NR & NR & NR & NR & NR & NR & NR & 19 & 25 \\
\hline $\mathrm{Cu}$ & NR & 27 & 250 & 40 & 170 & NR & NR & NR & NR & 900 & NR & NR & NR & 75 & 110 \\
\hline $\mathrm{Ti}$ & NR & 40 & NR & 80 & 285 & NR & NR & NR & NR & NR & NR & NR & NR & 114 & 81 \\
\hline
\end{tabular}

$\begin{array}{ll}a & \text { Kim and Kim (2003) } \\ b & \text { Clean Air Initiatives for Asian cities (2006). Air Quality in Asian cities, 6 p., } \\ & \text { http://www.cleanairnet.org/caiasia/1412/article-59689.html } \\ c & \text { Zheng et al. (2004) } \\ d & \text { Hea et al. (2001) } \\ e & \text { Chan et al. (2005) } \\ f & \text { Ho et al. (2003) } \\ g & \text { Sun et al. (2004) }\end{array}$

$\begin{array}{ll}h & \text { Wang et al. (2003) } \\ i & \text { Karar et al. (2007) } \\ j & \text { Mönkkönen et al. (2004) } \\ k & \text { Balachandran et al. (2000) } \\ l & \text { Kumar et al. (2001) } \\ m & \text { Rojas-Bracho et al. (2002) } \\ n & \text { Bogo et al. (2003) } \\ \text { NR } & \text { Not reported }\end{array}$

\subsection{PM composition}

As shown in Table 4, TSP, $\mathrm{PM}_{10}$ and $\mathrm{PM}_{2.5}$ levels in Mexico City are highly influenced by crustal material $\left(\mathrm{SiO}_{2}+\mathrm{CO}_{3}^{2-}+\mathrm{Al}_{2} \mathrm{O}_{3}+\mathrm{Ca}+\mathrm{Fe}+\mathrm{Mg}+\mathrm{K}\right): 25-27 \%$ of $\mathrm{PM}_{10}$ $\left(13-15 \mu \mathrm{g} / \mathrm{m}^{3}\right)$ in urban sites, and 36 and $43 \%$ in the suburban site $\mathrm{T} 1$ and at the industrial hotspot Jasso (36 and $27 \mu \mathrm{g} / \mathrm{m}^{3}$, respectively); confirming that the high $\mathrm{PM}_{10}$ levels recorded at these sites are partly due to dust resuspension. In $\mathrm{PM}_{2.5}$ this contribution decreased but still reached relatively high levels $\left(15-28 \%, 6-9 \mu \mathrm{g} / \mathrm{m}^{3}\right.$ at most sites), this being in agreement with previous works (Miranda et al., 1996; Vega et al., 2001). This crustal influence is also observed when studying the samples under the scanning electron microscope (SEM). Approximately $50 \%$ of the particles observed are minerals, mostly silicates (quartz, clays, micas, feldspars), but also phosphates, carbonates (calcite and siderite) and sulfates (gypsum). Applying the algorithm used by Chow et al. (2002): $(1.89 \times \mathrm{Al}+2.14 \times \mathrm{Si}+1.4 \times \mathrm{Ca}+1.43 \times \mathrm{Fe})$ the mineral matter content for these samples is about $18 \%$ less than when calculating it with our methodology, although the correlation coefficient between the two methods is very high $\left(\mathrm{R}^{2}=0.99\right)$.
The carbonaceous aerosols (OM+EC) also accounted for a high proportion of the PM mass: $32-46 \% \mathrm{PM}_{10}$ (18$23 \mu \mathrm{g} / \mathrm{m}^{3}$, with the highest values for T0) in urban sites, 35$37 \%\left(14-27 \mu \mathrm{g} / \mathrm{m}^{3}\right)$ at both industrial influenced sites, and less than $23 \%\left(8-13 \mu \mathrm{g} / \mathrm{m}^{3}\right)$ in the suburban and rural sites $\mathrm{T} 1$ and $\mathrm{T} 2$. In $\mathrm{PM}_{2.5}$ this contribution increased up to $55 \%$ and $30 \%$ in the urban and suburban sites, respectively, and from 51 to $53 \%$ at the industrial sites. The ratio EC/OC in $\mathrm{PM}_{10}$ determined in the present study varied from 0.2 to 0.6 for the different sites (with the exception of $\mathrm{T} 1$, where the ratio was close to 1 ). An EC/OC ratio of 0.2 for $\mathrm{T} 1$ was reported by Doran et al. (2007). The average EC/OC ratio at Tula was 0.4 (for $\mathrm{PM}_{2.5}$ and $\mathrm{PM}_{10}$ ), which is consistent with those values reported by Vega et al. (2007) for Salamanca (0.4 and 0.3 for $\mathrm{PM}_{2.5}$ and $\mathrm{PM}_{10}$, respectively) which is also an industrial area influenced by a refinery and a power plant.

At the urban sites of CENICA and T0 $\left(\mathrm{PM}_{10}\right)$, and at the suburban site $\mathrm{T} 1\left(\mathrm{PM}_{2.5}\right)$ there is a significant correlation of $\mathrm{K}$ and $\mathrm{OC}+\mathrm{EC}\left(\mathrm{R}^{2}=0.4-0.6\right)$, but also of $\mathrm{K}$ and $\mathrm{Al}$ $\left(\mathrm{R}^{2}=0.5-0.8\right)$ pointing to the relevance of both biomass combustion and mineral dust (K-feldspars and illite) emissions 

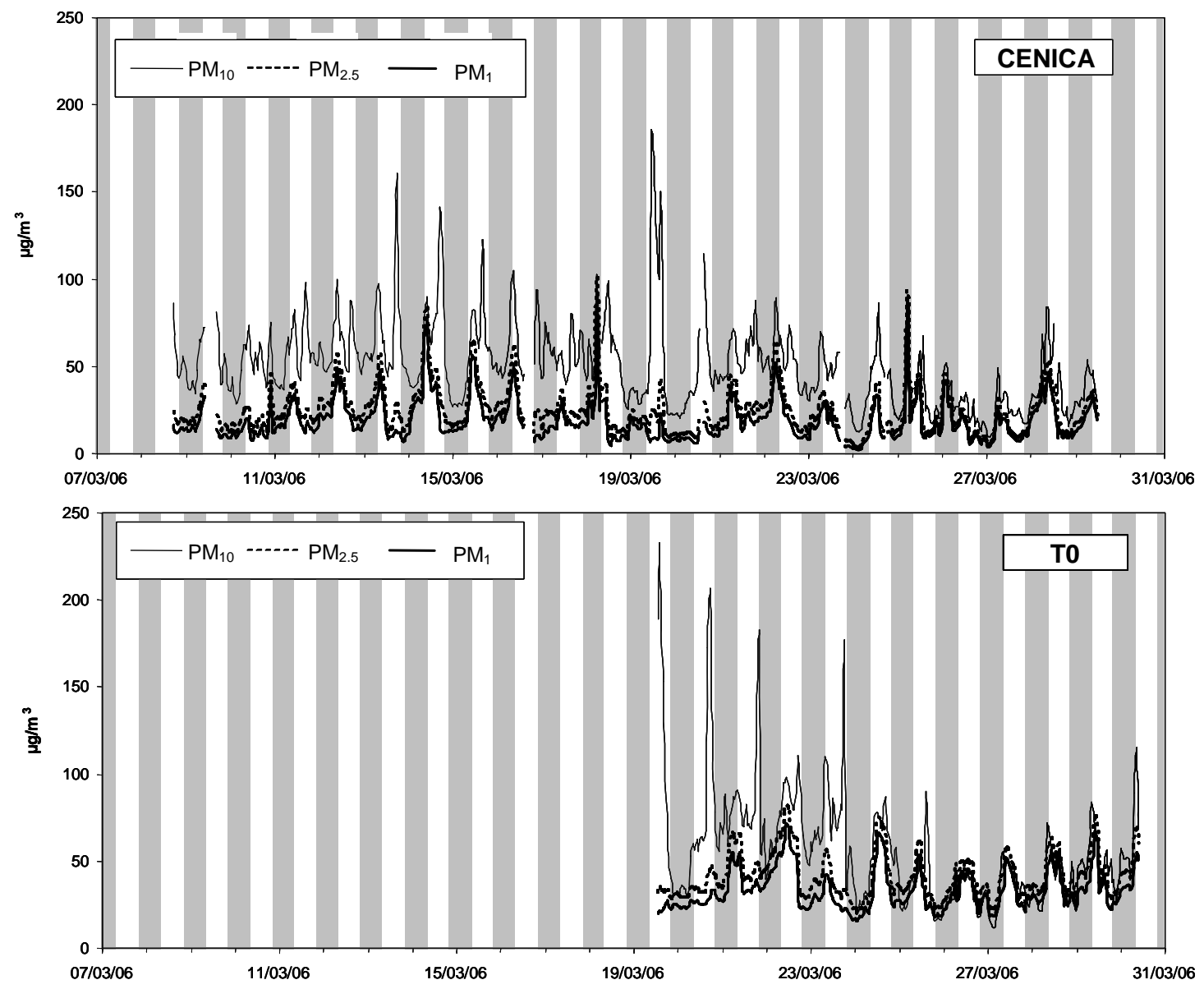

Fig. 7. Hourly PM levels measured during the MILAGRO campaign at 2 urban background sites of Mexico City, CENICA and T0.

contributing to the variability of the levels of these components. The influence of biomass combustion on $\mathrm{OC}+\mathrm{EC}$ levels also diminishes the typical urban correlation between nitrate and $\mathrm{OC}+\mathrm{EC}$ levels. Biomass burning episodes and their important influence on PM levels and composition in Mexico were previously reported by Johnson et al. (2006), Salcedo et al. (2006), Yokelson et al. (2007), Moffett et al. (2007), Molina et al. (2007), Stone et al. (2007) and Zang et al. (2007). These studies provided quantitative estimations of the contribution from biomass burning to PM levels, which vary widely according to the different authors. As described above, the influence of biomass burning on PM composition was detected in the present study, even though the current data does not enable us to provide an accurate estimation of the magnitude of this source contribution. By applying the factors relating biomass burning carbon with total OC by Stone et al. (2007) to the data from the present study, our results suggest that biomass burning contributions to $\mathrm{PM}_{2.5}$ at T0 should range between $5-15 \%$.

Secondary inorganic aerosols $\left(\mathrm{SIA}=\mathrm{SO}_{4}^{2-}+\mathrm{NO}_{3}^{-}+\mathrm{NH}_{4}^{+}\right)$ accounted for $15-20 \%$ of $\mathrm{PM}_{10}$ and $\mathrm{PM}_{2.5}$ mass at the urban sites, $10-19 \%$ at the suburban site, and $20-40 \%$ at the industrial sites, with sulfate accounting for around 50-65\% of SIA. Levels of ammonium $\left(1.1-1.5 \mu \mathrm{g} / \mathrm{m}^{3}\right.$ in $\left.\mathrm{PM}_{10}\right)$ and sulfate (4-5 $\mu \mathrm{g} / \mathrm{m}^{3}$ in $\mathrm{PM}_{10}$ ) were homogenous at the different urban, suburban and rural sites, and relatively higher at the industrial sites $\left(2.0-2.5 \mu \mathrm{g} \mathrm{NH}_{4}^{+} / \mathrm{m}^{3}\right.$ and $6.5 \mu \mathrm{g} \mathrm{SO}_{4}^{2-} / \mathrm{m}^{3}$ in $\mathrm{PM}_{10}$ ), this low spatial variability agrees with Salcedo et al. (2006), who concluded that sulfate in MCMA has mostly a regional character. Nitrate levels were relatively low, but higher at the urban sites $\left(2.8-3.6 \mu \mathrm{g} / \mathrm{m}^{3}\right.$ in $\mathrm{PM}_{10}$ and $\left.\mathrm{PM}_{2.5}\right)$, compared with the suburban and rural $\left(1.1-2.8 \mu \mathrm{g} / \mathrm{m}^{3}\right)$ and industrial $\left(0.6-1.8 \mu \mathrm{g} / \mathrm{m}^{3}\right)$ sites. Levels of SIA in $\mathrm{PM}_{2.5}$ were only slightly reduced with respect to $\mathrm{PM}_{10}$ for $\mathrm{SO}_{4}^{2-}$ and $\mathrm{NO}_{3}^{-}$in the urban sites. These results coincide with those obtained for $\mathrm{PM}_{2.5}$ at the CENICA site during the MCMA2003 Campaign, when similar levels of sulfate $\left(3.1 \mu \mathrm{g} / \mathrm{m}^{3}\right)$, nitrate $\left(3.7 \mu \mathrm{g} / \mathrm{m}^{3}\right)$ and ammonium $\left(2.2 \mu \mathrm{g} / \mathrm{m}^{3}\right)$ were registered (Salcedo et al., 2006). In the suburban site T1 SIA levels in $\mathrm{PM}_{2.5}$ were markedly reduced for nitrate due to the major occurrence of coarser $\mathrm{Ca}$ and $\mathrm{Na}$ nitrate species. This was also found by Fountoukis et al. (2007), who estimated $30 \%$ of nitrate being in the coarse fraction during 21th-30th March 2006, similar to our $39 \%$ during the same period. It is 


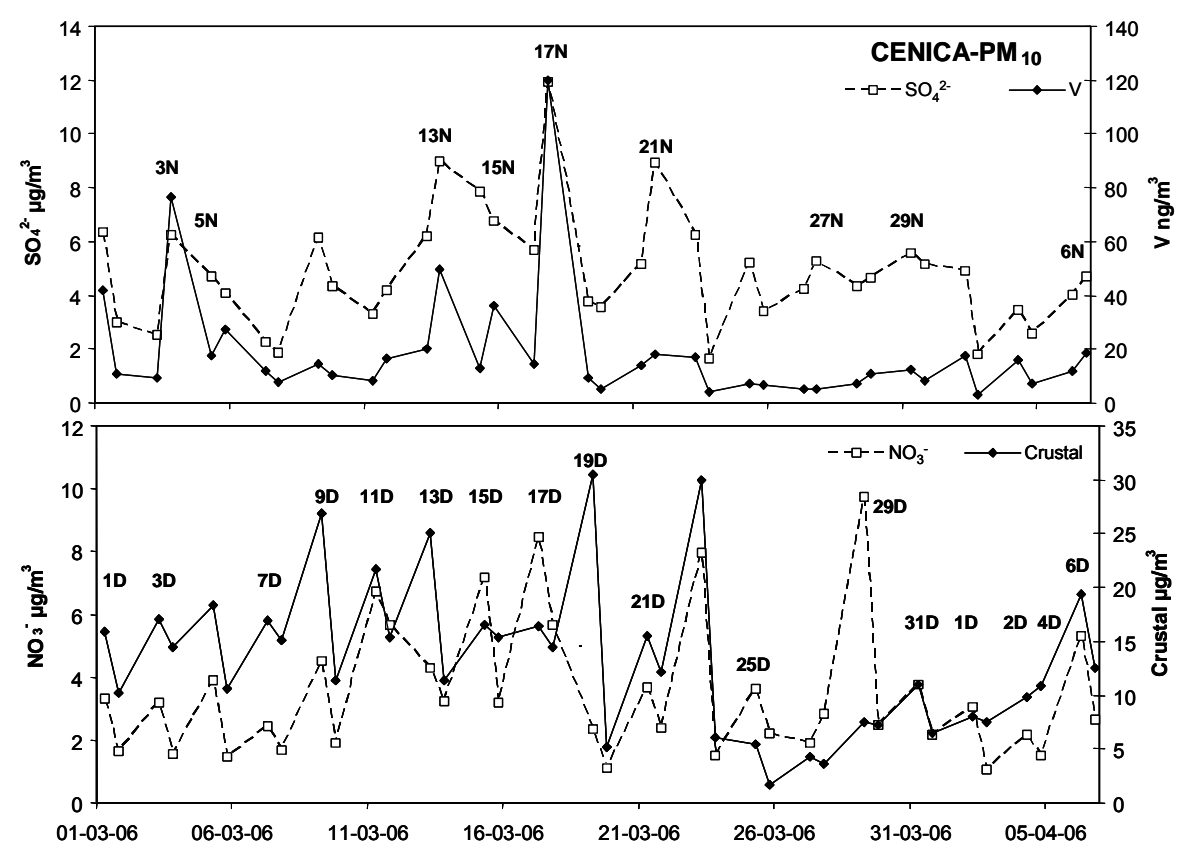

Fig. 8. Mean $12 \mathrm{~h}$ levels of $\mathrm{SO}_{4}^{2-}, \mathrm{NO}_{3}^{-}, \mathrm{V}$ and crustal material recorded at CENICA during the MILAGRO campaign. N, maximum value recorded in the nighttime sample; $\mathrm{D}$ maximum value recorded in the daylight sample.

interesting to note that the above described fine PM episodes (overnight trapping of pollutants in Mexico City and during the morning hours) coincide with the peak levels of ammonium sulfate, $\mathrm{V}$ and $\mathrm{Ni}$ (tracers of fuel-oil combustion and regional/urban background PM climate). Thus, Figs. 8 and 9 show the occurrence of these sulfate-vanadium episodes at CENICA, and Fig. 9 evidences a very good correlation between the levels of the above tracers recorded at CENICA and T0. The levels of most crustal elements and $\mathrm{Hg}$ exhibit a good correlation between the two urban sites. Figure 8 also evidences that nitrate and crustal material episodes are recorded during daytime and do not coincide with the above regional episodes, but are more related with local pollution episodes. This is also corroborated by Fig. 9, showing lower correlation between levels of nitrate, $\mathrm{Ba}$ and $\mathrm{Zn}$ (usually associated with road traffic emissions and consequently higher at T0) measured at the two urban sites when compared with sulfate. This is also the case of As and $\mathrm{Zr}$, with relatively higher levels being recorded at CENICA and with a low correlation with $\mathrm{T} 0$.

As expected the marine aerosols accounted for a very low fraction of $\mathrm{PM}_{10}$ ( $<1.5 \%$ in most cases).

As previously reported for PM levels, with the exception of carbonaceous aerosols and $\mathrm{V}$, levels of major components and trace elements in PM are usually much lower (one order of magnitude in some cases) during the MILAGRO campaign than those reported from other large cities (Table 3 and Table 4). Levels in $\mathrm{PM}_{10}$ of As $\left(5-7 \mathrm{ng} / \mathrm{m}^{3}\right)$, $\mathrm{Zn}\left(100-500 \mathrm{ng} / \mathrm{m}^{3}\right), \mathrm{Cd}\left(1-3 \mathrm{ng} / \mathrm{m}^{3}\right)$ and $\mathrm{V}\left(20-50 \mathrm{ng} / \mathrm{m}^{3}\right)$ were relatively high when compared with most urban sites from the US and Europe, or with values reported from Mexico city during 1996-1998 (Mugica et al., 2002) or during MCMA-2003 campaign (Johnson et al., 2006). However, the limit and target values for $\mathrm{Ni}, \mathrm{Pb}, \mathrm{Cd}$ and $\mathrm{As}$ from the EU (1999/30/CE and 2004/107/CE) were met with the exception of As (exceeding slightly the EU target value of 6 $\mathrm{ng} / \mathrm{m}^{3}$ ). Once again, it is essential to remember that the data obtained during the MILAGRO campaign do not represent annual mean values. The presence of metals in these samples has also been observed in the SEM, with most of them containing $\mathrm{Ba}$ (irregular in shape and interpreted as derived from traffic, probably brake linings), $\mathrm{Fe}$ (from condensed

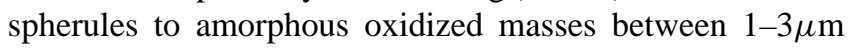
in size) or $\mathrm{Pb}$ (usually $1 \mu \mathrm{m}$ or less in size, and commonly spheroidal). Particles of other individual metals are much rarer but include $\mathrm{Cu}, \mathrm{Zn}, \mathrm{Mn}, \mathrm{W}, \mathrm{Sb}, \mathrm{Ni}$ (with $\mathrm{V}$ ), and $\mathrm{Mo}$, all of which are again very fine grained (usually sub-micron).

According to the above data, $\mathrm{PM}_{10}$ at the urban and industrially influenced areas is mainly made up of $\mathrm{OM}+\mathrm{EC}$ (32-46\%), crustal material (25-27\% urban, $15-35 \%$ industrial) and SIA (15-19\% urban, 14-29\% industrial). The unaccounted material (mostly water and heteroatoms in organic matter) accounts for 3 to $29 \%$ of the $\mathrm{PM}_{10}$ mass, whereas the trace elements account for 1 to $2 \%$ of the mass. At the rural sites, the proportion of crustal material increases to $32-43 \%$, whereas OM+EC diminishes down to 16-23\% (Fig. 10). The prevalence of carbonaceous aerosols in the PM composition detected in this study is consistent with the results by Chow et al. (2002) and Salcedo et al. (2006). In PM 2.5 (Fig. 10) the crustal material is reduced (but still present in relatively high 

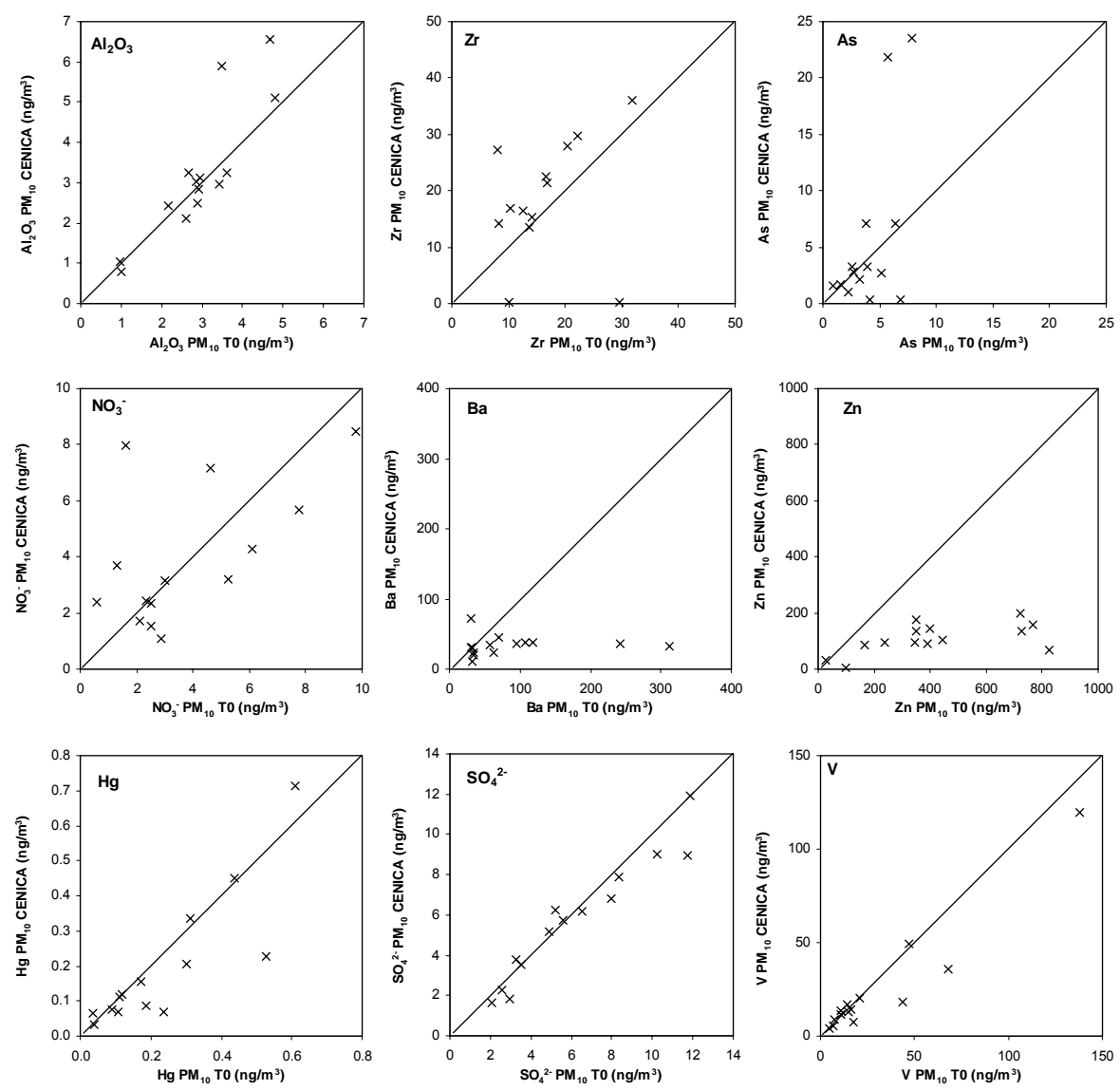

Fig. 9. Correlation between levels of $\mathrm{Al}_{2} \mathrm{O}_{3}, \mathrm{Zr}, \mathrm{As}, \mathrm{NO}_{3}^{-}, \mathrm{Ba}, \mathrm{Zn}, \mathrm{Hg}, \mathrm{V}$ and $\mathrm{SO}_{4}^{2-}$ in $\mathrm{PM}_{10}$ at CENICA and T0.

proportions) in the urban area down to $15 \%$ and to $8-17 \%$ in the industrially influenced sites, but it is still present in around $30 \%$ at the suburban site of $\mathrm{T} 1$ due to high local soil resuspension. Conversely, the proportions of carbonaceous aerosols increase up to $55 \%$ at the urban and industrial sites and $30 \%$ at the suburban site.

As shown in Fig. 11 crustal elements are generally present in the coarse fraction, especially at $\mathrm{T} 1$, where they are present in the fraction $>10 \mu \mathrm{m}$ in a significant proportion $\left(\mathrm{PM}_{10} / \mathrm{TSP}\right.$ ratio 04-0.6). The higher $\mathrm{PM}_{2.5} / \mathrm{PM}_{10}$ ratios were measured at the urban and industrial sites ( 0.4 at $\mathrm{T} 0$ and Jasso) when compared with the suburban (0.3) site, due to the major anthropogenic origin of the mineral matter in the first locations (road dust, demolition, limestone quarry, cement plants, etc). The other elements, mostly with a major anthropogenic origin, are mainly present in the fine fraction, with $\mathrm{PM}_{2.5} / \mathrm{PM}_{10}$ and $\mathrm{PM}_{10} / \mathrm{TSP}$ ratios usually $>0.6$, but in many cases $>0.8$. However, in some cases, where soil resuspension is important (T1) some elements such as Ni may have an important coarse proportion $\left(\mathrm{PM}_{2.5} / \mathrm{PM}_{10}\right.$ and $\mathrm{PM}_{10} / \mathrm{TSP}$ ratios close to 0.3 ).
At the urban sites, levels of major and trace crustal components and nitrate were significantly higher during the daylight period than during the night (Fig. 8), by a factor day/night ranging from 1.0 to 1.9 (with the highest values at CENICA) for $\mathrm{PM}_{10}$, as a consequence of higher emissions (from road traffic and from resuspension). Conversely, as shown in Fig. 8, levels of sulfate, chloride and most anthropogenic trace elements $(\mathrm{Hg}, \mathrm{V}, \mathrm{Ni}, \mathrm{Cu}, \mathrm{Zn}, \mathrm{As}, \mathrm{Se}, \mathrm{Mo}, \mathrm{Cd}, \mathrm{Sn}, \mathrm{Ba}$ and $\mathrm{Pb}$ ) were higher at night (by a factor of $0.8-1.0,0.5-0.7$ and $0.4-0.9$, respectively) probably due, as previously stated, to the reduction of the mixing layer depth. Carbonaceous aerosols increased as a mean also during the night at the urban site $\mathrm{T} 0$ by a factor of 1.2 and at the suburban site $\mathrm{T} 1$ by a factor of 1.5. At the urban site CENICA day and night levels of these components were very similar.

According to the transport and synoptic scenarios described by Fast et al. (2007) for the MILAGRO campaign, atmospheric transport form Mexico City over the suburban site T1 occurred on 10th, 18th, 19th, 20th, 22nd, and 24th March 2006. From these days sampling took place only during 9th10th and 19th-20th. As it may be observed in Fig. 12, the atmospheric transport from Mexico City is traced at $\mathrm{T} 1$ by the increase of nitrate and potassium in $\mathrm{PM}_{2.5}$, whereas the 

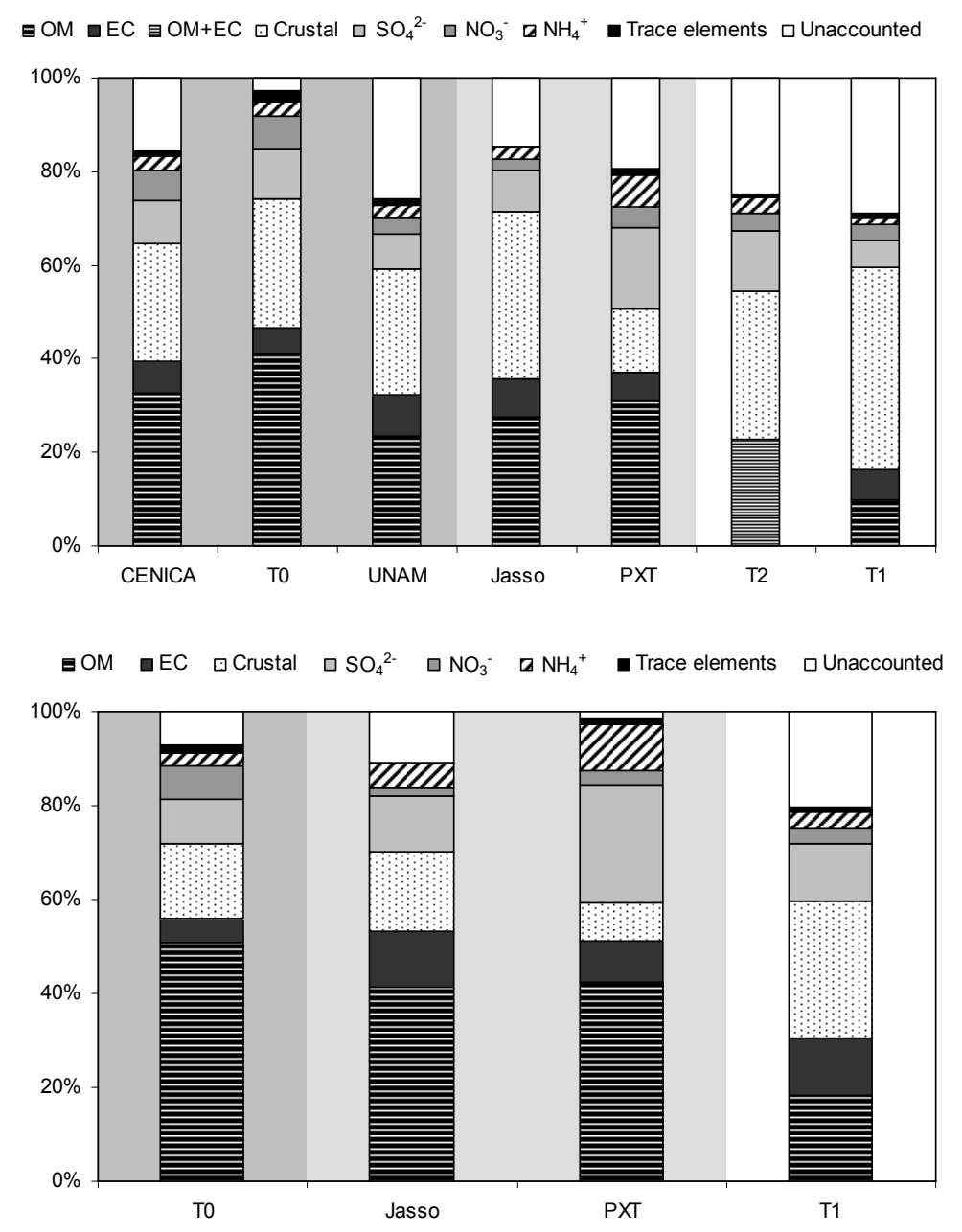

Fig. 10. Mean $\mathrm{PM}_{10}$ (top) and $\mathrm{PM}_{2.5}$ (bottom) composition obtained at urban (dark grey), industrial-rural (clear grey) and suburban and rural sites. Separate OM and EC data were unavailable for T2 site, and therefore their sum (OM+EC) is plotted for this site only.

transport from Tula industrial estate is traced by the increase of sulfate levels on 21st March 2006.

\subsection{Statistical analysis}

Comparing the mean levels of trace elements measured at the different study sites in the present work and with the distribution of major PM components, the following source origins may be identified:

- Crustal origin (soil and/or urban dust): Li, Be, P, Sc, $\mathrm{Ti}, \mathrm{Mn}, \mathrm{Co}, \mathrm{Ga}, \mathrm{Ge}, \mathrm{Rb}, \mathrm{Sr}, \mathrm{Y}, \mathrm{Zr}, \mathrm{Nb}, \mathrm{Cs}$, Rare Earth Elements, Hf, U, Th.

- Urban (mostly road traffic): Cr, $\mathrm{Mn}, \mathrm{Cu}, \mathrm{Zn}, \mathrm{As}, \mathrm{Se}, \mathrm{Cd}$, $\mathrm{Sn}, \mathrm{Sb}, \mathrm{Ba}$ and $\mathrm{Pb}$, typically associated with road traffic emissions (engine emissions, abrasion of tyres and brake pads).

- Industrial around Tula: $\mathrm{Pb}, \mathrm{Cr}$ and $\mathrm{V}$ (other elements such as $\mathrm{Cd}$, As, Ni were not analyzed here).
- Industrial and regional (petrochemical estate, fuel oil, petcoke combustion): $\mathrm{V}, \mathrm{Ni}$ and sulfate.

Particulate $\mathrm{Hg}$ is not higher at the urban sites than at the suburban site $\mathrm{T} 1$, consequently, as previously reported, it has an external (regional) origin to the city. However, local sources, such as a hazardous waste incinerator and a petrochemical plant may also contribute to increase $\mathrm{Hg}$ in a much minor proportion (González et al., 2007).

These findings were confirmed by performing a statistical analysis of the different datasets, by means of Principal Component Analysis (PCA) with the software STATISTICA v.4.2. This kind of factor analysis requires a minimal internal variability, and therefore it was only applied to the datasets containing $>25$ samples (CENICA, T0 and T1). However, the number of samples $(25,35$ and 38 at T1, T0 and CENICA, respectively) was lower than the minimum number of cases required according to Henry et al. (1984) $(\mathrm{n}>30+(\mathrm{V}+3) / 2$, where $\mathrm{n}$ is the number of samples and $\mathrm{V}$ is the number of variables). Consequently, in order to confirm 
Table 4. Mean TSP, $\mathrm{PM}_{10}$ and $\mathrm{PM}_{2.5}$ levels and major components $\left(\mu \mathrm{g} / \mathrm{m}^{3}\right)$ recorded at the study sites during the MILAGRO campaign.

\begin{tabular}{|c|c|c|c|c|c|c|c|c|c|c|c|c|}
\hline & \multirow{2}{*}{$\begin{array}{l}\text { CENICA } \\
\mathrm{PM}_{10}\end{array}$} & \multicolumn{2}{|c|}{ T0 } & \multicolumn{3}{|c|}{$\mathrm{T} 1$} & \multirow{2}{*}{$\begin{array}{l}\mathrm{T} 2 \\
\mathrm{PM}_{10}\end{array}$} & \multirow{2}{*}{$\begin{array}{l}\text { UNAM } \\
\mathrm{PM}_{10}\end{array}$} & \multicolumn{2}{|c|}{ Jasso } & \multicolumn{2}{|c|}{ PXT } \\
\hline & & $\mathrm{PM}_{10}$ & $\mathrm{PM}_{2.5}$ & PST & $\mathrm{PM}_{10}$ & $\mathrm{PM}_{2.5}$ & & & $\mathrm{PM}_{10}$ & $\mathrm{PM}_{2.5}$ & $\mathrm{PM}_{10}$ & $\mathrm{PM}_{2.5}$ \\
\hline $\mathrm{n}$ & 38 & 36 & $27^{2.5}$ & 23 & 24 & $25^{2.5}$ & 8 & 7 & 28 & 28 & 27 & $27^{2.5}$ \\
\hline PM & 53 & 50 & 40 & 193 & 82 & 33 & 34 & 54 & 75 & 31 & 37 & 26 \\
\hline $\mathrm{OC}$ & 10.8 & 12.9 & 12.4 & 8.0 & 5.0 & 3.7 & ND & 8.0 & 12.9 & 8.0 & 7.1 & 6.8 \\
\hline $\mathrm{EC}$ & 3.6 & 2.7 & 2.1 & 5.6 & 5.3 & 4.0 & ND & 4.7 & 6.0 & 3.6 & 2.2 & 2.2 \\
\hline $\mathrm{CO}_{3}^{2-}$ & 2.0 & 2.3 & 0.9 & 9.2 & 4.2 & 1.1 & 1.3 & 2.3 & 13.8 & 2.5 & 1.4 & 0.5 \\
\hline $\mathrm{SiO}_{2}$ & 5.1 & 4.9 & 2.4 & 34.6 & 15.7 & 4.0 & 4.7 & 5.6 & 2.4 & 0.6 & 1.4 & 0.9 \\
\hline $\mathrm{Ca}$ & 1.3 & 1.5 & 0.6 & 6.2 & 2.8 & 0.7 & 0.9 & 1.5 & 9.2 & 1.7 & 0.9 & 0.3 \\
\hline $\mathrm{K}$ & 0.7 & 0.7 & 0.3 & 1.9 & 1.1 & 0.6 & 0.5 & 0.6 & 0.2 & 0.1 & 0.1 & 0.2 \\
\hline $\mathrm{Na}$ & 0.5 & 0.5 & 0.3 & 1.6 & 0.8 & 0.3 & 0.2 & 0.4 & 0.2 & 0.1 & 0.1 & 0.1 \\
\hline $\mathrm{Mg}$ & 0.5 & 0.4 & 0.1 & 1.8 & 0.9 & 0.3 & 0.3 & 0.4 & 0.3 & 0.1 & 0.1 & 0.04 \\
\hline $\mathrm{Fe}$ & 0.9 & 1.1 & 0.4 & 4.2 & 2.0 & 0.6 & 0.6 & 1.0 & 0.6 & 0.1 & 0.6 & 0.2 \\
\hline $\mathrm{SO}_{4}^{2-}$ & 4.9 & 5.3 & 3.7 & 6.3 & 4.8 & 3.9 & 4.4 & 4.2 & 6.4 & 3.7 & 6.4 & 6.4 \\
\hline $\mathrm{NO}_{3}^{-}$ & 3.5 & 3.6 & 2.8 & 4.2 & 2.8 & 1.1 & 1.2 & 1.8 & 1.8 & 0.6 & 1.6 & 0.8 \\
\hline $\mathrm{Cl}^{-}$ & 0.4 & 0.4 & 0.7 & 0.5 & 0.3 & 0.2 & 0.1 & 0.1 & 0.1 & 0.2 & 0.1 & 0.1 \\
\hline
\end{tabular}

the validity of the results PCA was applied separately to the $\mathrm{PM}_{10}$ datasets from T0, CENICA and T1, and it was also applied to a larger dataset made up of the combination of the CENICA and T0 samples, with similar results. This confirmed the robustness of the solution.

The results for CENICA were very similar to those for T0, and thus are not included in the description below. At the urban locations (CENICA and T0), four main factors were identified (representing the main source categories):

Factor 1: the main tracers of this factor were $\mathrm{Al}_{2} \mathrm{O}_{3}, \mathrm{Ti}, \mathrm{Mg}, \mathrm{Fe}, \mathrm{Ca}$, $\mathrm{P}, \mathrm{K}, \mathrm{Na}, \mathrm{Mn}$, Th, Ce, Zr, suggesting the clearly mineral origin of this source. This factor probably represents mineral dust resuspension in the city, both road/city and soil dust. The daily evolution of the contribution to the PM mass of this factor showed a marked decrease after 23rd March 2006, coinciding with the washout of road and city dust by precipitation.

Factor 2:

this factor was characterized by $\mathrm{SO}_{4}^{2-}, \mathrm{V}, \mathrm{Ni}, \mathrm{NH}_{4}^{+}$and $\mathrm{Hg}$, and it was interpreted as regional-scale transport. The contribution from $\mathrm{SO}_{4}^{2-}$ and $\mathrm{NH}_{4}^{+}$suggests long-range transport, and once again the correlation between these species and $\mathrm{Hg}$ is observed and it confirms the regional origin of $\mathrm{Hg}$. The fact that $\mathrm{Ni}$ and $\mathrm{V}$ are also found in this factor shows that the impact from fuel-oil combustion emissions such as those registered in the Tula industry estate may be detected in Mexico City under specific air mass transport scenarios (regionalscale transport).

Factor 3:

$\mathrm{Sr}, \mathrm{Cu}, \mathrm{Ba}, \mathrm{Pb}, \mathrm{Cr}, \mathrm{C}, \mathrm{Zn}$ and $\mathrm{Cd}$ were the main tracers of this source, which was interpreted as road traffic. SEM-EDX observations confirmed this association of metals. This source was the only one presenting slight differences between T0 and CENICA, probably due to the larger traffic influence in T0. Whereas the factor loadings of major and primary traffic tracers were higher at $\mathrm{TO}(\mathrm{C}, \mathrm{Cu}, \mathrm{Ba}, \mathrm{Pb})$, it was the secondary or minor traffic tracers that were highest at CENICA $\left(\mathrm{NO}_{3}^{-}, \mathrm{Rb}, \mathrm{Cd}\right)$. This confirms that even though traffic emissions are dominant at both urban sites, their impact is more direct in the case of T0 than of CENICA.

Factor 4:

the last factor was characterized by $\mathrm{As}, \mathrm{Zr}$, Th, $\mathrm{Ce}$, and $\mathrm{Cr}$, and the nature of this source is yet unclear. This combination of elements could suggest the resuspension of volcanic dust deposited on the city roads, or the influence of an additional source affecting both urban sites.

In the case of the $\mathrm{T} 1$ suburban site, five factors were identified:

Factor 1:

with Fe, Ti, Mn, $\mathrm{Al}_{2} \mathrm{O}_{3}, \mathrm{Ce}, \mathrm{Mg}$, Th, K, Rb, Sr, Ba, Na, Zr, $\mathrm{Cr}, \mathrm{Ca}$ and $\mathrm{P}$ as main tracers, the nature of this source was interpreted as mineral, although some differences may be observed with the mineral source in T0 and CENICA. While the chemical profile in T1 suggests the prevalence of clay minerals, in T0 and CENICA a mixture is observed between clay minerals, carbonates and K-feldspars among others (higher factor loadings for $\mathrm{Ca}, \mathrm{P}, \mathrm{K}$ ) originating from construction and demolition activities in the city.

Factor 2:

this factor was characterized by $\mathrm{Pb}, \mathrm{Cd}, \mathrm{Cu}$ and $\mathrm{Zn}$ and it represents an anthropogenic source of PM, probably linked to industrial emissions which could be related to small smelting plants located to the northeast of Mexico City (R. Moffett, personal communication).

Factor 3:

with $\mathrm{NH}_{4}^{+}$and $\mathrm{SO}_{4}^{2-}$ as its main tracers, this source clearly represents regional-scale transport. $\mathrm{Hg}$ was also found to correlate with this source, even though the highest factor loading for this element was found in Factor 4.

Factor 4:

$\mathrm{Sb}, \mathrm{As}, \mathrm{C}, \mathrm{NO}_{3}^{-}$and $\mathrm{Cd}$ were the main tracers of this source, which coincided largely with the traffic source at the urban sites. Thus, this source could be interpreted as the 
Table 5. Mean levels of trace components in $\mathrm{TSP}, \mathrm{PM}_{10}$ and $\mathrm{PM}_{2.5}\left(\mathrm{ng} / \mathrm{m}^{3}\right)$ recorded at the study sites during the MILAGRO campaign. NA: not available.

\begin{tabular}{|c|c|c|c|c|c|c|c|c|c|c|c|c|}
\hline & \multirow{2}{*}{$\begin{array}{l}\text { CENICA } \\
\mathrm{PM}_{10}\end{array}$} & \multicolumn{2}{|c|}{ T0 } & \multicolumn{3}{|c|}{$\mathrm{T} 1$} & \multirow{2}{*}{$\begin{array}{l}\mathrm{T} 2 \\
\mathrm{PM}_{10}\end{array}$} & \multirow{2}{*}{$\begin{array}{l}\text { UNAM } \\
\mathrm{PM}_{10}\end{array}$} & \multicolumn{2}{|c|}{ Jasso } & \multicolumn{2}{|c|}{ PXT } \\
\hline & & $\mathrm{PM}_{10}$ & $\mathrm{PM}_{2.5}$ & TSP & $\mathrm{PM}_{10}$ & $\mathrm{PM}_{2.5}$ & & & $\mathrm{PM}_{10}$ & $\mathrm{PM}_{2.5}$ & $\mathrm{PM}_{10}$ & $\mathrm{PM}_{2.5}$ \\
\hline $\mathrm{n}$ & 38 & 36 & 27 & 23 & 24 & 25 & 8 & 7 & 28 & 28 & 27 & 27 \\
\hline $\mathrm{Hg}$ & 0.14 & 0.22 & 0.13 & 0.40 & 0.28 & 0.18 & 0.04 & 0.11 & NA & NA & NA & NA \\
\hline $\mathrm{Li}$ & 0.4 & 0.5 & 0.4 & 2.2 & 1.0 & 0.2 & 0.1 & 0.5 & NA & NA & NA & NA \\
\hline $\mathrm{Be}$ & 0.05 & 0.05 & 0.04 & 0.57 & 0.27 & 0.12 & 0.05 & 0.05 & NA & NA & NA & NA \\
\hline $\mathrm{P}$ & 100 & 120 & 53 & 304 & 166 & 48 & 72 & 106 & NA & NA & NA & NA \\
\hline $\mathrm{Sc}$ & 0.6 & 0.6 & 0.5 & 1.6 & 1.0 & 0.5 & 0.2 & 1.1 & NA & NA & NA & NA \\
\hline V & 19 & 25 & 13 & 27 & 17 & 10 & 9 & 16 & 50 & 30 & 21 & 18 \\
\hline $\mathrm{Cr}$ & 0.7 & 4.4 & 2.1 & 4.9 & 1.5 & 0.9 & 0.1 & 1.9 & 20 & 15 & 192 & 102 \\
\hline $\mathrm{Mn}$ & 20 & 32 & 16 & 83 & 41 & 13 & 15 & 23 & NA & NA & NA & NA \\
\hline Co & 0.5 & 0.8 & 0.5 & 1.6 & 0.9 & 0.2 & 0.3 & 0.5 & NA & NA & NA & NA \\
\hline $\mathrm{Ni}$ & 3 & 5 & 3 & 9 & 5 & 2 & 1 & 3 & NA & NA & NA & NA \\
\hline $\mathrm{Cu}$ & 78 & 110 & 90 & 103 & 33 & 27 & 13 & 140 & 13 & 11 & 10 & 5 \\
\hline $\mathrm{Zn}$ & 103 & 482 & 244 & 187 & 165 & 97 & 8 & 98 & 21 & 11 & 11 & 5 \\
\hline $\mathrm{Ga}$ & 0.4 & 0.4 & 0.3 & 1.9 & 1.2 & 0.4 & 0.4 & 0.1 & NA & NA & NA & NA \\
\hline As & 6 & 6 & 6 & 4 & 3 & 2 & 1 & 7 & NA & NA & NA & NA \\
\hline $\mathrm{Se}$ & 7 & 6 & 6 & 3 & 3 & 3 & 1 & 7 & NA & NA & NA & NA \\
\hline $\mathrm{Rb}$ & 0.9 & 0.9 & 0.5 & 2.5 & 1.8 & 1.0 & 0.6 & 0.7 & NA & NA & NA & NA \\
\hline $\mathrm{Sr}$ & 9 & 16 & 5 & 38 & 18 & 5 & 5 & 9 & NA & NA & NA & NA \\
\hline $\mathrm{Y}$ & 0.3 & 0.2 & 0.1 & 1.8 & 0.9 & 0.2 & 0.1 & 0.2 & NA & NA & NA & NA \\
\hline $\mathrm{Zr}$ & 20 & 18 & 15 & 45 & 29 & 22 & 6 & 23 & NA & NA & NA & NA \\
\hline $\mathrm{Nb}$ & 0.4 & 0.4 & 0.3 & 1.9 & 1.1 & 0.4 & 0.3 & 0.5 & NA & NA & NA & NA \\
\hline Mo & 1 & 2 & 2 & 8 & 5 & 3 & 0.1 & 0.1 & NA & NA & NA & NA \\
\hline $\mathrm{Cd}$ & 2 & 3 & 3 & 1 & 1 & 1 & 0.3 & 2 & NA & NA & NA & NA \\
\hline $\mathrm{Sn}$ & 23 & 32 & 29 & 12 & 14 & 9 & 4 & 7 & NA & NA & NA & NA \\
\hline $\mathrm{Sb}$ & 15 & 16 & 15 & 10 & 10 & 8 & 3 & 8 & NA & NA & NA & NA \\
\hline Cs & 0.1 & 0.1 & 0.1 & 0.3 & 0.2 & 0.1 & $<0.1$ & 0.2 & NA & NA & NA & NA \\
\hline $\mathrm{Ba}$ & 30 & 92 & 22 & 82 & 43 & 12 & 3 & 27 & NA & NA & NA & NA \\
\hline $\mathrm{La}$ & 1.3 & 0.8 & 0.7 & 0.4 & 1.2 & 0.5 & 0.7 & 0.5 & NA & NA & NA & NA \\
\hline $\mathrm{Ce}$ & 1.6 & 1.5 & 1.2 & 6.9 & 4.1 & 1.1 & 1.0 & 1.5 & NA & NA & NA & NA \\
\hline $\mathrm{Hf}$ & 0.7 & 0.6 & 0.5 & 1.4 & 0.9 & 0.7 & 0.2 & 0.8 & NA & NA & NA & NA \\
\hline $\mathrm{Tl}$ & 0.6 & 0.4 & 0.3 & 0.3 & 0.5 & 0.2 & $<0.1$ & 0.3 & NA & NA & NA & NA \\
\hline $\mathrm{Th}$ & 0.1 & 0.1 & 0.1 & 1.1 & 0.5 & 0.1 & 0.1 & 0.2 & NA & NA & NA & NA \\
\hline $\mathrm{U}$ & 0.3 & 0.3 & 0.2 & 0.5 & 0.4 & 0.4 & 0.2 & 0.4 & NA & NA & NA & NA \\
\hline
\end{tabular}

contribution from local traffic but also as the transport towards T1 of the emissions from Mexico City. This factor has also high loadings for $\mathrm{K}$ and $\mathrm{Hg}$.

Factor 5:

$\mathrm{V}$ and $\mathrm{Ni}$ were the main tracers of this source, which was interpreted as fuel-oil combustion probably from the petrochemical estate in Tula. It is interesting to observe that at T1 the regional source does not include the contributions from $\mathrm{V}$ and $\mathrm{Ni}$, which were detected jointly at the urban sites. This indicates that the impact from the emissions from the petrochemical estate is registered at T1 under specific air mass transport scenarios, which do not always coincide with regional-scale transport as in the case of the urban sites.

It is interesting to note that biomass burning emissions were not identified as a single source in any of the factor analyses performed. Instead, tracers of these emissions (K) were correlated with the mineral and regional-fuel oil combustion sources. The non-identification of this source may be related to its probably low contribution to the $\mathrm{PM}_{10}$ mass compared to other sources during the study period. Also the limited number of samples available (25-38 samples/site), the short duration of the campaign, and the fact that specific tracers (OC, WSOC, water-soluble $\mathrm{K}$ ) were not available for all samples may account for the non identification of this source. However, the correlation between $\mathrm{OC}+\mathrm{EC}$ and $\mathrm{K}$ levels described above (Sect. 4.2) evidences the influence of this source on PM levels and composition. Potassium in $\mathrm{PM}_{2.5}$ was also detected as tracer of the Mexico's plume at a rural site in this study. Thus the contribution of biomass burning to $\mathrm{PM}_{10}$ and $\mathrm{PM}_{2.5}$ was detected but in much minor proportions than reported by other authors by modeling. Furthermore, for finer aerosols (such as $\mathrm{PM}_{1}$ ) this source may probably contribute in a larger extend due to the reduction of the mineral matter load (containing also K).

\section{Conclusions}

The levels of PM during the MILAGRO campaign (1st to 31 st March 2006) ranged from 50 to $56 \mu \mathrm{g} \mathrm{PM}_{10} / \mathrm{m}^{3}, 24$ to $40 \mu \mathrm{g} \mathrm{PM}_{2.5} / \mathrm{m}^{3}$ and 19 to $33 \mu \mathrm{g} \mathrm{PM}_{1} / \mathrm{m}^{3}$ in Mexico City. Although these levels may be considered as relatively high 

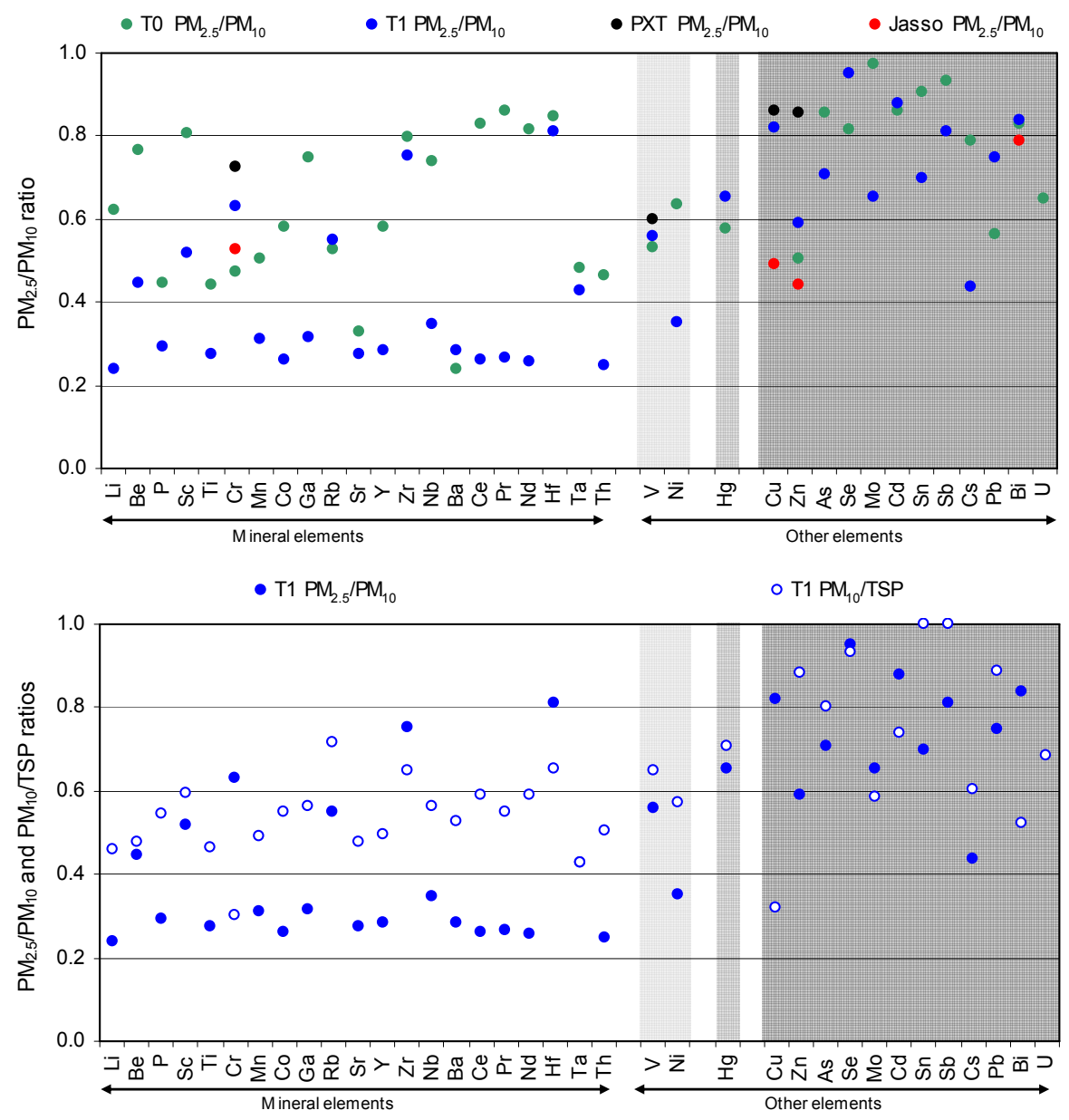

Fig. 11. $\mathrm{PM}_{2.5} / \mathrm{PM}_{10}$ ratios of trace elements levels at $\mathrm{T} 0$, $\mathrm{T} 1$, Jasso and PXT. $\mathrm{PM}_{10} / \mathrm{TSP}$ levels at $\mathrm{T} 1$.

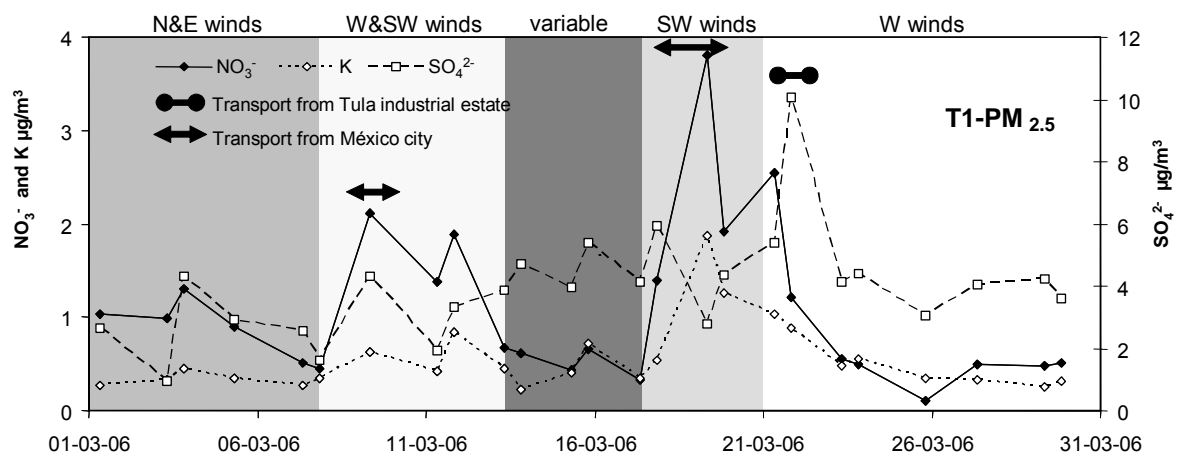

Fig. 12. $12 \mathrm{~h}$ levels (daylight and night) of nitrate, potassium and sulfate in $\mathrm{PM}_{2.5}$ measured at the T1 suburban site on 1st, 3rd, 5th, 7th, 9th, 11th, 13th, 16th, 17th, 19th, 21st, 23rd, 25th, 27th and 29th March 2006. Note that nitrate and potassium trace the transport from Mexico City, whereas sulfate is mainly tracing the transport from Tula industrial estate. The transport and synoptic scenarios described by Fast et al. (2007) for the MILAGRO campaign are also marked in the plot.

when compared with US or European air quality standards, they are markedly lower than PM levels measured at Asian mega-cities.

Daily variations of PM levels were recorded in parallel at the urban sites within the city, despite the distance between the sites (approx. $20 \mathrm{~km}$ ). This suggests that the variability of PM levels and composition in Mexico City are determined by atmospheric dynamics, more specifically by the 
mixing layer height, rather than by emission sources. Strong PM peak episodes originated by the decreasing mixing layer height were detected on a number of days between 04:00 and 06:00 h.

Important day-night variations were also observed: the levels of crustal components and $\mathrm{NO}_{3}^{-}$presented higher levels during daytime (coinciding with Chow et al., 2002 and Salcedo et al., 2006), while $\mathrm{SO}_{4}^{2-}$ concentrations and most of anthropogenic trace metals presented higher levels during night hours.

The analysis of air mass transport scenarios demonstrated the impact of the emissions from Mexico City on the levels and chemical composition of PM on surrounding areas. On days when winds originated from the north/north-west, the impact of the Mexico City plume was clearly detected at the rural background site in Tenango. Conversely, under the influence of winds from the south/south-east, the influence of the Mexico City plume was detected at the T1 site, with nitrate and potassium in $\mathrm{PM}_{2.5}$ being identified as major tracers. Finally, westerly circulations evidenced the influence of the emissions from Tula (petrochemical estate) on the chemical composition of PM at T1.

The statistical analysis of the $\mathrm{PM}_{10}$ data from $\mathrm{T} 0$, CENICA and T1 by PCA resulted in four sources at the urban sites (CENICA and T0), and five sources at the suburban site (T1). At the urban locations the main PM sources were mineral dust (both road/city and soil dust), regional-scale transport (including $\mathrm{Hg}$ ), traffic emissions and an unidentified As source. Traffic emissions were characterized by primary tracers at $\mathrm{T} 0$, whereas secondary tracers were highest at CENICA, confirming that the impact of traffic emissions is more direct in T0 than in CENICA. At T1 the main PM sources were mineral dust, industrial emissions, regional-scale transport, local traffic (also interpreted as the transport towards $\mathrm{T} 1$ of the emissions from Mexico City), and oil combustion originating probably from the petrochemical estate in Tula. The interpretation of the traffic source at all sites was confirmed by the observation of $\mathrm{Ba}, \mathrm{Fe}, \mathrm{Cu}$ and $\mathrm{Pb}$ particles by SEM-EDX.

Supplementary material: http://www.atmos-chem-phys. net/8/111/2008/acp-8-111-2008-supplement.zip

Acknowledgements. This study was supported by the Acción Complementaria from the Ministry of Education and Science of Spain CGL2005-23745-E. We also thank the support from the Spanish Ministry of the Environment. We would like also to thank W. Eichinger from the University of Iowa for making available the meteorological data at $\mathrm{T} 0$ during the campaign.

Edited by: L. Molina

\section{References}

Aldape, F., Flores M. J., Flores A. J., Retama-Hernandez, A., and Rivera-Hernandez, O: Elemental composition and source identification of PM2.5 particles collected in downtown Mexico City, International Journal PIXE, 15, 263-270, 2005.

Balachandran, S., Meena, B. R., and Khillare, P. S.: Particle size distribution and its elemental composition in the ambient air of Delhi, Environ. Int., 26, 49-54, 2000.

Bogo, H., Otero, M., Castro, P., Ozafrán, M. J., Kreiner, A., Calvo, E. J., Negri, R. M.: Study of atmospheric particulate matter in Buenos Aires city, Atmos. Environ., 37, 1135-1147, 2003.

CAFÉ: Clean Air for Europe: European Commission, Second Position Paper on Particulate Matter - CAFE Working Group on Particulate Matter, D.G. Environment, April 2004, 1-234, 2004.

Chan, C. Y., Xu, X. D., Li, Y. S., Wong, K. H., Ding, G. A., Chan, L. Y., and Cheng, X. H.: Characteristics of vertical profiles and sources of PM2.5, PM10 and carbonaceous species in Beijing, Atmos. Environ., 39, 5113-5124, 2005.

Chow, J. C., Watson, J. C., Edgerton S. A., and Vega, E.: Chemical composition of PM2.5 and PM10 in Mexico City during winter 1997, Sci. Total Environ., 287, 177-201, 2002.

Clean Air Initiatives for Asian cities: Air Quality in Asian cities, 1-6, available at:http://www.cleanairnet.org/caiasia/1412/ article-59689.html, 2006.

Dockery D., Pope C., Xu, X., Spengler, J., Ware, J., Fay, M., Ferris, B., and Speizer, F.: An association between air pollution and mortality in six US cities, New Engl. J. Med., 329, 1753-1759, 1993.

Doran, J. C., Arnott, W. P., Barnard, J. C., Cary, R., Coulter, R., Fast, J. D., Kassianov, E. I., Kleinman, L., Laulainen, N. S., Martin, T., Paredes-Miranda, G., Pekour, M. S., Shaw, W. J., Smith, D. F., Springston, S. R., and Yu, X.-Y.: The T1-T2 study: evolution of aerosol properties downwind of Mexico City, Atmos. Chem. Phys., 7, 1585-1598, 2007, http://www.atmos-chem-phys.net/7/1585/2007/.

Fast, J. D. and Zhong, S.: Meteorological factors associated with inhomogeneous ozone concentrations within the Mexico City basin, J. Geophys. Res., 103, 18 927-18 946, 1998.

Fast, J. D., de Foy, B., Acevedo Rosas, F., Caetano, E., Carmichael, G., Emmons, L., McKenna, D., Mena, M., Skamarock, W., Tie, X., Coulter, R. L., Barnard, J. C., Wiedinmyer, C., and Madronich, S.: A meteorological overview of the MILAGRO field campaigns, Atmos. Chem. Phys., 7, 2233-2257, 2007, http://www.atmos-chem-phys.net/7/2233/2007/.

Fountoukis, C., Nenes, A., Sullivan, A., Weber, R., VanReken, T., Fischer, M., Matías, E., Moya, M., Farmer, D., and Cohen, R. C.: Thermodynamic characterization of Mexico City aerosol during MILAGRO 2006, Atmos. Chem. Phys. Discuss., 7, 9203-9233, 2007, http://www.atmos-chem-phys-discuss.net/7/9203/2007/.

Fung, K, Chow, J, and Watson, J.: Evaluation of OC/EC Specition by Thermal Manganese Dioxide Oxidation and the IMPROVE Method, Air Waste Manage., 52, 1333-1341, 2002.

González, R., Márquez, C., Bernabé, R., Snyder, D. C., Rutter, A. P., Minguillón, M. C., Pérez, N., Pey, J., Alverdin, L., Reyes, E., Miranda, L., Miranda, J., Moreno, T., Blanco, S., De la Rosa, A., Solórzano, G., Alastuey, A., Schauer, J., Querol, X., de Foy, B., Molina, L. T., and Cárdenas, B.: A43A-20 Measurements of Total Gaseous and Particulate Mercury in Mexico City During the 
MCMA-2006/MILAGRO Campaign. Eos Trans. AGU, 88(23), Jt. Assem. Suppl., Abstract A43A-20, 2007.

Hea, K., Yang, F., Ma, Y., Zhang, Q., Yao, X., Chan, Ch.K., Cadle, S., Chan, T., and Mulawa, P.: The characteristics of PM2.5 in Beijing, China, Atmos. Environ., 35, 4959-4970, 2001.

Henry, R. C., Lewis, C. W., Hopke, P. K., and Williamson, H. J.: Review of receptor model fundamentals, Atmos. Environ., 18, $1507-1515,1984$.

Ho, K. F., Lee, S. C., Chan, C. K., Yu, J.C., Chow, J. C., and Yao, X.H.: Characterization of chemical species in PM2.5 and PM10 aerosols in Hong Kong, Atmos. Environ., 37, 31-39, 2003.

Johnson, K. S., de Foy, B., Zuberi, B., Molina, L. T., Molina, M. J., Xie, Y., Laskin, A., and Shutthanandan, V.: Aerosol composition and source apportionment in the Mexico City Metropolitan Area with PIXE/PESA/STIM and multivariate analysis, Atmos. Chem. Phys., 6, 4591-4600, 2006,

http://www.atmos-chem-phys.net/6/4591/2006/.

Karar, K. and Gupta, A. K.: Source apportionment of PM10 at residential and industrial sites of an urban region of Kolkata, India, Atmos. Res., 84, 30-41, 2007.

Kim, K.-H. and Kim, M.-Y.: The effects of Asian Dust on particulate matter fractionation in Seoul, Korea during spring 2001, Chemosphere, 51, 707-721, 2003.

Künzli, N., Kaiser, R., Medina, S., Studnicka, M., Chanel, O., Filliger, P., Herry, M., Horak, F. Jr., Puybonnieux-Texier, V., Quénel, P., Schneider, J., Seethaler, R., Vergnaud, J.-C., and Sommer, H.: Public health impact of outdoor and traffic-related air pollution: a tri-national European assessment, Lancet, 356, 795-801, 2000.

Kumar, A. V., Patil, R. S., and Nambi, K. S. V.: Source apportionment of suspended particulate matter at two traffic junctions in Mumbai, India, Atmos. Environ., 35, 4245-4251, 2001.

Miranda, J., Andrade, E., Lopez-Suarez, A., Ledesma, R., Cahill, T. A., and Wakabayashi, P. H.: A receptor model for atmospheric aerosols from a southwestern site in Mexico City, Atmos. Environ., 30, 3471-3479, 1996.

Miranda, J., Barrera, V. A., Espinosa, A. A., Galindo, O. S., and Meinguer, J.: PIXE analysis of atmospheric aerosols in Mexico City, X-Ray Spectrom., 34, 391-401, 2005.

Moffett, R. C., de Foy, B., Molina, L. T., Molina, M. J., and Prather, K. A.: Measurement of ambient aerosols in northern Mexico City by single particle mass spectrometry, Atmos. Chem. Phys. Discuss., 7, 6413-6457, 2007,

http://www.atmos-chem-phys-discuss.net/7/6413/2007/.

Molina, L. T., Kolb, C. E., de Foy, B., Lamb, B. K., Brune, W. H., Jimenez, J. L., Ramos-Villegas, R., Sarmiento, J., ParamoFigueroa, V. H., Cardenas, B., Gutierrez-Avedoy, B., and Molina, M. J.: Air quality in North America's most populous city overview of the MCMA-2003 campaign, Atmos. Chem. Phys., 7, 2447-2473, 2007, http://www.atmos-chem-phys.net/7/2447/2007/.

Mönkkönen, P., Uma, R., Srinivasan, D., Koponen, I. K., Lehtinen, K. E. J., Hämeri, K., Suresh, R., Sharma, V. P., and Kulmala, M.: Relationship and variations of aerosol number and PM10 mass concentrations in a highly polluted urban environmentNew Delhi, India, Atmos. Environ., 38, 425-433, 2004.

Mugica, V., Maubert, M., Torres, M., Muñoz, J., and Rico, E.: Temporal and Spatial Variations of Metal Content in TSP and PM10 in Mexico City during 1996-1998, J. Aerosol Sci., 33(1), 91-
102, 2002.

Querol, X., Alastuey, A., Rodríguez, S., Plana, F., Ruiz, C. R., Cots, N., Massagué, G., and Puig, O.: PM10 and PM2.5 source apportionment in the Barcelona Metropolitan Area, Catalonia, Spain, Atmos. Environ., 35/36, 6407-6419, 2001.

Rojas-Bracho, L., Suh, H. H., Oyola, P., and Koutrakis, P.: Measurements of children's exposures to particles and nitrogen dioxide in Santiago, Chile, The Science of The Total Environment, 287, 3, 249-264, 2002.

Salcedo, D., Onasch, T. B., Dzepina, K., Canagaratna, M. R., Zhang, Q., Huffman, J. A., DeCarlo, P. F., Jayne, J. T., Mortimer, P., Worsnop, D. R., Kolb, C. E., Johnson, K. S., Zuberi, B., Marr, L. C., Volkamer, R., Molina, L. T., Molina, M. J., Cardenas, B., BernabÉ, R. M., Márquez, C., Gaffney, J. S., Marley, N. A., Laskin, A., Shutthanandan, V., Xie, Y., Brune, W., Lesher, R., Shirley, T., and Jimenez, J. L.: Characterization of ambient aerosols in Mexico City during the MCMA-2003 campaign with Aerosol Mass Spectrometry: results from the CENICA Supersite, Atmos. Chem. Phys., 6, 925-946, 2006,

http://www.atmos-chem-phys.net/6/925/2006/.

Stone, E. A., Snyder, D. C., Sheesley, R. J., Sullivan, A. P., Weber, R. J., and Schauer J. J.: Source apportionment of fine organic aerosol in Mexico City during the MILAGRO Experiment 2006, Atmos. Chem. Phys. Discuss., 7, 9635-9661, 2007, http://www.atmos-chem-phys-discuss.net/7/9635/2007/.

Sun, Y., Zhuang, G., Wang, Y., Han, L., Guo, J., Dan, M., Zhang, W., Wang, Z., and Hao, Z.: The air-borne particulate pollution in Beijing concentration, composition, distribution and sources, Atmos. Environ., 38, 5991-6004, 2004.

Turpin, B. J. and Lim, H.J.: Species Contributions to PM2.5 Mass Concentrations: Revisiting Common Assumptions for Estimating Organic Mass, Aerosol Sci. Tech., 35, 602-610, 2001.

Vega, E., Mugica, V., Reyes, R., Sánchez, E., Chow, J., and Watson, J.: Chemical Composition of Fugitive Dust Emitters in Mexico City, Atmos. Environ., 35, 4033-4039, 2001.

Vega, E., Reyes, E., Ruiz, H., Garcia, J., Sanchez, G., MartinezVilla, G., Gonzalez, U.: Analysis of PM2.5 and PM10 in the atmosphere of Mexico City during 2000-2002, J. Air Waste Manage., 54(7), 786-798, 2004.

Vega, E., Ruiz, H., Martinez-Villa, G., Sanchez, G., Sosa, G., Gonzalez-Avalos, E., Reyes, E., and Garcia, J.: Fine and Coarse Particulate Matter Chemical Characterization in a Heavily Industrialized City in Central Mexico during Winter 2003, J. Air Waste Manage., 57, 620-633, 2007.

Volkamer, R., Jimenez, J. L., SanMartini, F., Dzepina, K., Zhang, Q., Salcedo, D., Molina, L. T., Worsnop, D. R., and Molina, M. J.:, Secondary organic aerosol formation from anthropogenic air pollution: Rapid and higher than expected, Geophys. Res. Lett., 33, L17811, doi:10.1029/2006GL026899, 2004.

Wang, G., Wang, H., Yu, Y., Gao, Sh., Feng, J., Gao, S., and Wang, L.: Chemical characterization of water-soluble components of PM10 and PM2.5 atmospheric aerosols in five locations of Nanjing, China, Atmos. Environ., 37, 2893-2902, 2003.

WHO: Health aspects of air pollution with particulate matter, ozone and nitrogen dioxide, World Health Organization, Report EUR/03/5042688, 1-98, 2003.

WHO: World Health Organization air quality guidelines global update 2005, 1-25, 2005.

WHO/UNEP: Urban Air Pollution in Megacities of the World, 
Blackwell, Oxford, 1992.

Yokelson, R., Urbanski, S., Atlas, E., Toohey, D., Alvarado, E., Crounse, J., Wennberg, P., Fisher, M., Wold, C., Campos, T., Adachi, K., Buseck, P. R., and Hao, W. M.: Emissions from forest fires near Mexico City, Atmos. Chem. Phys. Discuss., 7, 6687-6718, 2007,

http://www.atmos-chem-phys-discuss.net/7/6687/2007/.

Zhang, Q., Jimenez, J. L. Canagaratna, M. R., Allan, J. D., Coe, H. Ulbrich, I., Alfarra, M. R., Takami, A., Middlebrook, A. M., Sun, Y.L., Dzepina, K., Dunlea, E., Docherty, K., DeCarlo, P. F., Salcedo, D., Onasch, T., Jayne, J. T., Miyoshi, T., Shimono, A., Hatakeyama, S., Takegawa, N., Kondo, Y., Schneider, J., Drewnick, F., Borrmann, S., Weimer, S., Demerjian, K., Williams, P., Bower, K., Bahreini, R., Cottrell, L., Griffin, R. J., Rautiainen, J., Sun, J. Y., Zhang, Y. M., and Worsnop, D. R.: Ubiquity and dominance of oxygenated species in organic aerosols in anthropogenically-influenced Northern Hemisphere midlatitudes, Geophys. Res. Lett., 34, L13801, doi:10.1029/2007GL029979, 2007.
Zheng, J., Tan, M., Shibata, Y., Tanaka, A., Li, Y., Zhang, G., Zhang, Y., and Shan, Z.: Characteristics of lead isotope ratios and elemental concentrations in PM10 fraction of airborne particulate matter in Shanghai after the phase-out of leaded gasoline, Atmos. Environ., 38, 1191-1200, 2004. 